\title{
TAPHONOMIC ANALYSIS OF THE LOWER PLEISTOCENE PIRRO NORD FOSSIL LOCALITY (PIRRO 10 SITE, PUGLIA, SOUTHERN ITALY): A DEPOSITIONAL MODEL FOR VERTEBRATE ASSEMBLAGES IN A KARSTIC ENVIRONMENT
}

\author{
MARTA ZUNINO, ${ }^{*}$ MARCO PAVIA, ${ }^{1}$ SIXTO R. FERNÁNDEZ-LÓPEZ, ${ }^{2}$ and GIULIO PAVIA ${ }^{1}$ \\ ${ }^{1}$ Dipartimento di Scienze della Terra, Università di Torino, Via Valperga Caluso 35, I-10125 Torino, Italy, marta.zunino@unito.it, marco.pavia@unito.it, \\ giulio.pavia@unito.it; 2Departamento y UEI de Paleontología, Facultad de Ciencias Geológicas (UCM) e Instituto de Geología Económica (CSIC-UCM), \\ 28040 Madrid, Spain,sixto@geo.ucm.es
}

\begin{abstract}
Taphonomic analyses have been conducted on the macromammal remains found in Sedimentary Unit 7 of the lower Pleistocene Pirro 10 site of the Pirro Nord locality in Italy. Recent field research has concentrated on investigating the fossil content of this site and the genesis of the karst network and its related deposits. In the present study, we distinguish between preburial and synsedimentary (during burial) processes in order to group the vertebrate remains into different taphonomic categories according to their various states of preservation, thus introducing the concept of taphorecord-borrowed from invertebrate taphonomy-into macrovertebrate taphonomy for the first time. Element quantification, evaluation of transport effects, and state of preservation of the skeletal elements were studied and all elements separated into four taphorecords according to their relative chronology. The use of taphorecords also improves the accuracy of the data obtained from the various methods of element quantification. The analysis of bone sorting and orientation indicates that the fossiliferous deposits originated by water flows carrying both fossils and sediments, alternating with phases of carcass accumulation and reelaboration of bones from previously deposited layers. The study presented here serves as a proof of concept for the use of taphorecords in analyses of fossiliferous deposits in caves.
\end{abstract}

\section{INTRODUCTION AND GEOLOGIC SETTING}

The Pirro Nord site is located near the municipality of Apricena (Foggia, Southern Italy) and consists of a widespread network of karst structures opened in Mesozoic limestones of the Calcare di Bari Formation that were filled by silty, sandy sediments containing a diversified lower Pleistocene vertebrate fossil assemblage (Grassi et al., 1982; Abbazzi et al., 1996; Pavia et al., 2010, 2011).

The presence of vertebrate remains in the Pirro Nord locality (or Cava Pirro or Cava Dell'Erba) first came to the attention of the scientific community thanks to studies by Freudenthal (Freudenthal, 1971). Subsequently, stratigraphic data and taxonomic analyses of the macromammal assemblages have highlighted the importance of this site; in particular, the Pirro Nord Faunal Unit constitutes a biochronological reference for the European late Villafranchian Land Mammal Age (De Giuli et al., 1987; Abbazzi et al., 1996; Gliozzi et al., 1997; Bertini et al., 2010; Rook and Martínez-Navarro, 2010).

Recently, new richly fossiliferous deposits were discovered in the Cava Dell'Erba area, among them two karst structures named Pirro 10 (P10) and Pirro 13 (P13), which are filled by silty to coarse-grained sediments and early Pleistocene vertebrate remains (Fig. 1). In particular, the discovery of lithic tools mixed with vertebrate bones referable to the Pirro Nord Faunal Unit (Arzarello et al., 2007, 2009) renewed interest in the locality leading to repeated systematic excavations since 2007 (Pavia et al., 2011) and to a stratigraphic

* Corresponding author.

Copyright $\odot$ 2012, SEPM (Society for Sedimentary Geology) revision of the Pliocene-Pleistocene marine succession of the ApricenaLesina-Poggio Imperiale quarry district that includes the karst deposits (Pavia et. al., 2010).

Paleomagnetic analyses carried out in August 2007 and July 2009 at P10 and P13, together with the collected biochronological data, suggest that the Pirro Nord sedimentary infill can be referred to a time interval from 1.7-1.3 Ma corresponding to Matuyama post-Olduvai Reverse Polarity Chron (Tema et al., 2009; Pavia et al., 2010, 2011), although not all authors agree with this dating; e.g., the infill is dated from 1.51.2 Ma according to Masini and Sala (2007) or 1.5-1.3 Ma following Bertini et al. (2010).

The aim of this paper is to present a taphonomic analysis of the macromammal assemblage from the P10 site and determine the factors that influenced the formation of this rich bone deposit. Data were recorded during the latest excavation campaign conducted by Torino University from 14 July to 25 August 2009. In particular, this report analyzes the fossils collected in Sedimentary Unit 7 (SU7; Pavia et al., 2011), and describes the vertebrate assemblage and the taphonomic parameters used to study them. We distinguish between preburial and synsedimentary or during-burial processes (including weathering, predation, and effect of burial in soils) in order to group the vertebrate remains into different taphonomic categories according to their state of preservation, thus allowing the definition of diverse paleontological units or taphorecords (Fernández-López, 1987). Moreover, interactions between bones and cave water before and after burial were also analyzed. Transport effects such as spatial distribution of the fossils, orientation of skeletal elements, and Voorhies' dispersal groups are described with special attention.

\section{Pirro 10 Gallery and Sedimentary Unit 7}

The P10 site was discovered in 2004 by a research team from Torino University (Pavia et al., 2008). The P10 gallery has an ellipsoidal cross section and a subhorizontal longitudinal profile. Sediments of Pirro 10 can be related to two main karst cycles: (1) a late Miocene-early Pliocene cycle with deposition of Terre Rosse and fossils of the Mikrotia Fauna; and (2) an early-middle Pleistocene cycle containing Villafranchian Land Mammal Age vertebrate remains (Abbazzi et al., 1996; Pavia et al., 2011). The most recent cycle developed during and after the early Pleistocene final emersion of the area inside the carbonate substratum constituted by the Mesozoic Calcare di Bari Formation and a Pliocene marine carbonate complex (Pavia et al., 2010). Dissolution was more effective along the fractured core zone of the Pliocene fault that bounded the Apricena horst to the south, resulting in a set of connected karst structures including, among others, P10 and P13 (Arzarello et al., 2011). The P13 structure represents a vertical shaft in the vadose zone that is connected with the surface, whereas the P10 infilling is linked to a series of fluctuations of base level. Periods of lowering of the local phreatic level led to the deposition of flowstones, whereas water flow circulation in phreatic and 

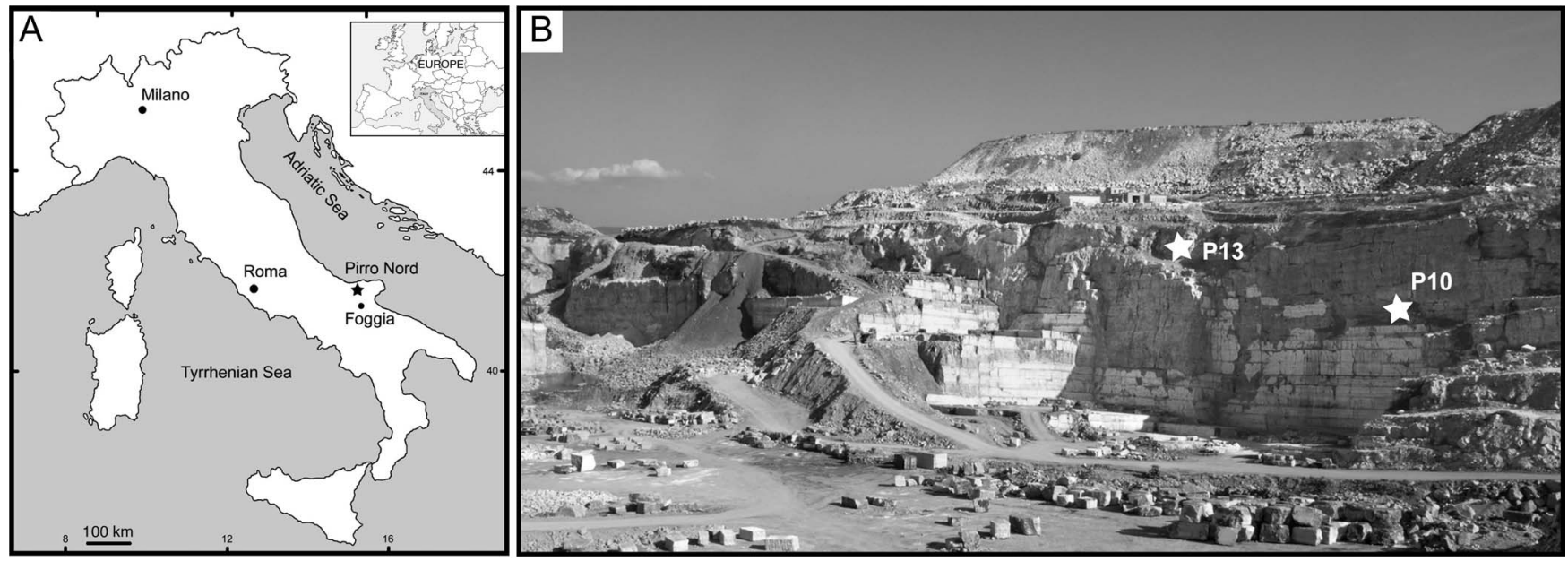

FIGURE 1-Study area in Italy. A) Location of the Pirro Nord locality. B) View of Dell'Erba quarry complex (formerly known as Pirro Nord quarries). Asterisks indicate the position of Pirro 10 (P10) and Pirro 13 (P13) karst structures (modified after Pavia et al., 2011).

epiphreatic conditions led to the deposition of clastic sediments (Pavia et al., 2011).

The karst structure extends for more than $25 \mathrm{~m}$ east to west, but unfortunately the real geometry of the gallery cannot be defined because its shape was altered by quarry works that destroyed part of the karstic structure. As a result of quarrying activity in recent years, the $\mathrm{P} 10$ site is now located about $40 \mathrm{~m}$ above the quarry floor and is inaccessible (Fig. 1). Since its discovery, more than 6000 vertebrate remains have been collected and catalogued in the collections of the Museo di Geologia e Paleontologia of Torino University with the acronym PU (Pavia and Pavia, 2004), in accordance with the Soprintendenza dei Beni Archeologici della Puglia.

The P10 site has been sampled based on a subdivision of the outcrop into four sectors (I-IV) and one meter squares (E-K starting from $\mathrm{N}$ to S; 10-35 from W to E; Pavia et al., 2011, fig. 2) to better describe and correlate the stratigraphic units across the whole P10 gallery. As described in Pavia et al. (2011), the P10 gallery is totally filled by clastic sediments organized into 37 superimposed sedimentary units (SU1-27 and SU101-110). Currently, due to the presence of concretionary structures influencing sedimentation in sector III, stratigraphic correlation between sectors III and IV is hardly detectable.

The lower Pleistocene succession crops out for at least $6 \mathrm{~m}$ in thickness in the P10 gallery and contains vertebrate remains mixed with marine invertebrate bioclasts derived from erosion of PliocenePleistocene marine deposits. Such deposits have been subdivided into seven minor phases based in particular on the presence of flowstones or short-lived episodes of speleothem formation alternating with clastic deposition of clay to very coarse gravel with channel structures.

The excavations in summer of 2009 focused particularly on Sedimentary Unit 7 (SU7), which is composed of $40-80 \mathrm{~cm}$ of gray to reddish clayey sands with discontinuous, more clayey lenses. SU7 is ubiquitous but its deposition in sector III was strongly affected by the presence in squares F10-11 of a dome structure $80-90 \mathrm{~cm}$ high made of a large, laminated pink flowstone and cemented breccia with Calcare di Bari Formation blocks. Three main subhorizontal levels of vertebrate remains associated with decalcified carbonate pebbles and plant remains are distinguished within SU7; they are labeled from the bottom to the top as $7 \mathrm{a}, 7 \mathrm{~b}$, and $7 \mathrm{c}$, and are referable to three different depositional events (Fig. 2). These three levels are separated only by the presence of bone alignments as they are lithologically indistinguishable. The data described in this paper refer to an area of $5 \mathrm{~m}^{2}$ which includes squares F12 and G12-G15 and is approximately quantifiable as $3 \mathrm{~m}^{3}$ of sediments; in these squares bones are subhorizontal in the levels except for those on level 7b in G12-G13 squares, which lie on a gentle slope $\left(\sim 15^{\circ}\right)$.

For further details on the geology, geomorphology, stratigraphy, and paleontology of the Pirro 10 site, see Pavia et al. $(2010,2011)$ and references therein.

\section{MATERIAL AND METHODS}

A total of 1830 mammal skeletal elements were found in SU7. Of these, 411 elements were classified to the specific level and 103 only to skeletal part; 1316 unidentifiable bone fragments (1260 fragments $<5 \mathrm{~cm} ; 56>5 \mathrm{~cm}$ ) were collected but not analyzed. The vertebrate assemblages of fossiliferous levels $7 \mathrm{a}-7 \mathrm{c}$ are dominated by Axis eurygonos and Hystrix refossa, along with Ursus etruscus, Homotherium latidens, and Panthera gombaszoegensis as common elements. The whole taxonomic composition is summarized in Table 1.

A classical approach to element quantification was performed, including analyses of the number of identified specimens (NISP), minimum number of individuals (MNI), and skeletal representation following previous authors (Badgley, 1986; Lyman, 1994; Mazza et al., 2004). NISP was calculated both by identified taxon and identified skeletal element. MNI was first valued on the basis of skeletal element, side, age (separating subadult from adult specimens only), size, and especially state of preservation, as traditionally recommended by several authors (Badgley, 1986; Lyman, 1994; Grayson and Frey, 2004). According to these studies, anatomical features are always used, whereas weathering stages are never clearly considered in the quantitative analysis of the abundance of remains. The examined bones belong to adults only, or less frequently, to subadults. The two age classes were detected by the presence of unfused epiphyses in long bones with dimensions comparable to those with fused epiphyses (Barone, 1995). No remains of newborns or very young individuals were found.

For a comprehensive study of skeletal representation, expected abundances were established by observing the frequencies of bones (see Mazza et al., 2004) and these were then corrected, taking into account the state of preservation of fossils and the distinction of taphorecords.

\section{Bone Surface Modification}

Bone surface modification can be defined as the surficial features resulting from biological (trampling, gnawing, scavenging), physical (load and/or tectonic deformation) and chemical (weathering, corro- 


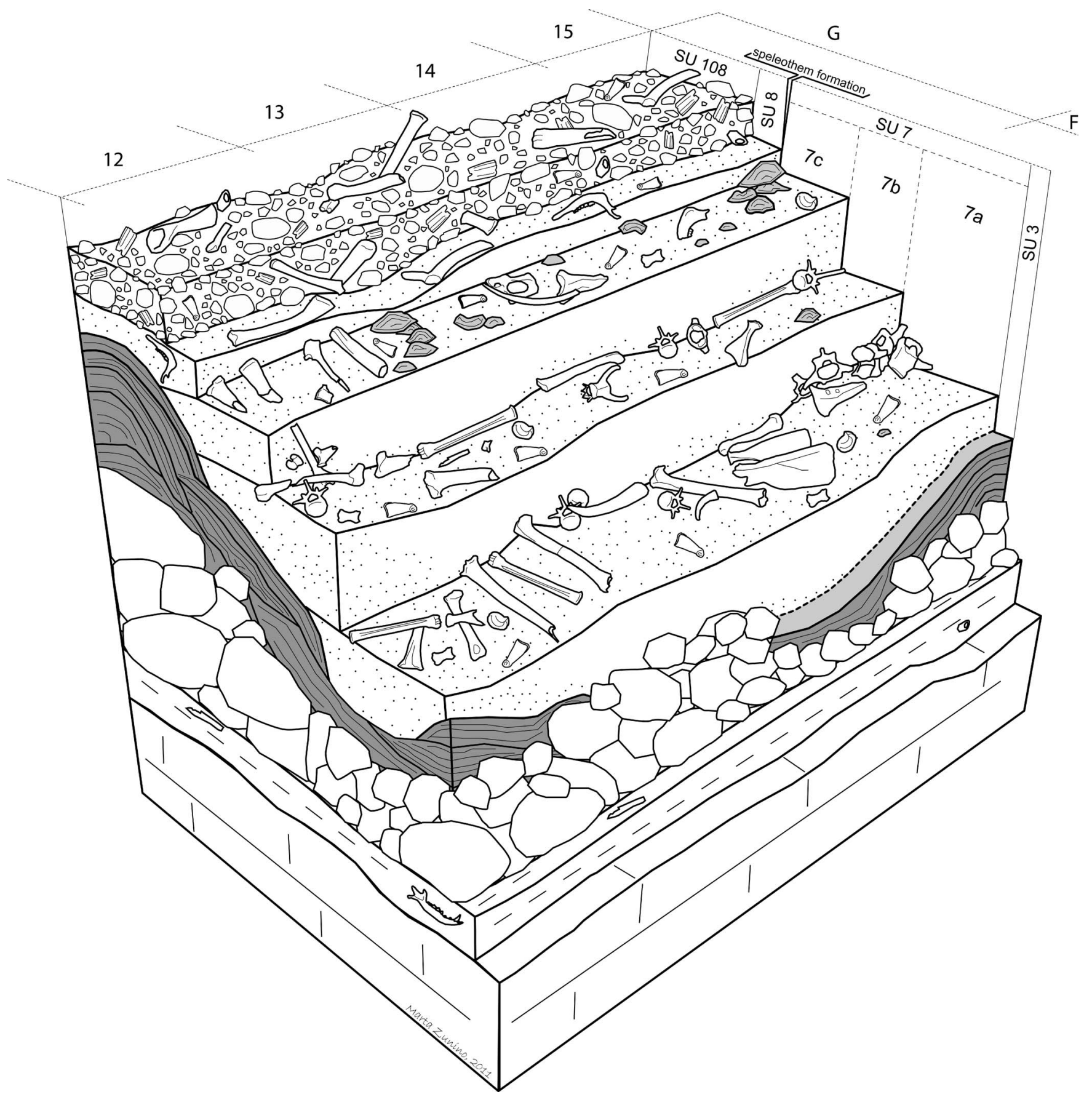

FIGURE 2-Three-dimensional sketch of the remains in Sedimentary Unit 7 (SU7) of the Pirro 10 site, showing the spatial distribution of bones in three successive stratigraphic levels. The sketch includes squares F12 and G12-G15 in sector III of the P10 gallery. The boundary between SU3 and SU7 units was not detected during the excavations in summer, 2009; SU4-6 are lacking. Although not shown in this reconstruction, a concretionary structure in squares F10-11 (Fig. 7) affected flow in the area shown (see text for further explanation).

sion, abrasion) processes active during postmortem to early burial stages (Fiorillo, 1991; Kos, 2003).

All large mammal specimens of SU7 (except isolated teeth) that could be identified to species or to skeletal element (7a: 239 remains; $7 \mathrm{~b}: 176$ remains; $7 \mathrm{c}$ : 23 remains) were analyzed. Aspects of the surficial condition studied included weathering stage, desquamation, pitting, oxidation and coloring of bones, presence of tooth marks, and abrasion stage. In particular, coloring of bones and stages of weathering were described in detail; features of bone fracturing, tooth marks, pitting, and abrasion were less conspicuously represented and were examined only briefly.

Different types of fractures were recognized following the outlines of Lyman (1994) and Kos (2003). Pitting was defined as the presence of subcircular cavities that penetrated the bone surface. Two different pitting morphologies were recognized; isolated depressions $0.1-3.0 \mathrm{~mm}$ in diameter and irregular depressions usually $>3.0 \mathrm{~mm}$ that originated by coalescence of adjacent cavities. Abrasion or wearing away by mechanical action were recognized as rounding and/or polishing of skeletal elements.

The presence of manganese oxides and coloring of bone surfaces were also detected; the former is linked to wet sedimentary conditions and is probably catalyzed by manganese-oxidizing bacteria (e.g., López-González et al., 2006). Two aspects of bone coloring were recorded; the area affected by the color and different morphologies of oxidation. 
TABLE 1-Macromammal taxa from the three fossiliferous levels of Sedimentary Unit 7, Pirro 10 site. NR = number of remains.

\begin{tabular}{lccc}
\hline \hline \multicolumn{1}{c}{ Taxon } & \multicolumn{3}{c}{$\mathrm{NR}$} \\
\cline { 2 - 4 } & $7 \mathrm{a}$ & $7 \mathrm{~b}$ & $7 \mathrm{c}$ \\
\hline Hystrix refossa & 38 & 23 & 5 \\
Ursus etruscus & 6 & 9 & 1 \\
Canis mosbachensis & 11 & 9 & - \\
Xenocyon lycaonoides & 13 & 4 & - \\
Vulpes alopecoides & - & 1 & - \\
Pachycrocuta brevirostris & 3 & 2 & 1 \\
Megantereon withei & - & 4 & - \\
Homotherium latidens & 4 & 7 & 3 \\
Panthera gombaszoegensis & 4 & 1 & 1 \\
Equus altidens & 3 & 9 & - \\
Axis eurygonos & 138 & 95 & 11 \\
Stephanorhinus cf. hundsheimensis & - & 1 & - \\
Bison (Eobison) degiulii & 3 & - & - \\
Praemegaceros obscurus & - & 1 & - \\
Undetermined & 57 & 210 & 2 \\
Total & 280 & & 24 \\
\hline
\end{tabular}

\section{Weathering Stages}

Weathering of bone surfaces results from physical and chemical processes operating both in subaerial conditions and within the soil zone. The effects and duration of weathering are well known in open-air environments (Behrensmeyer, 1978; Lyman and Fox, 1989), but no comprehensive studies have been carried out on weathering modification in karst environments, resulting in a lack of standards for comparisons between different sites. Some authors have, however, adapted Behrensmeyer's stages to individual case studies (e.g., Díez et al., 1999; Kos, 2003). In the present paper, these classical stages of weathering (Behrensmeyer, 1978) were slightly modified (see Table 2) to better fit the SU7 characteristics. No temporal assignment could be inferred for each stage because no case history in karst environments is available. Actualistic data (Behrensmeyer, 1978) indicate a strong correlation between weathering stage displayed by carcasses and the number of years since the animal died, and a variable degree of weathering in some open-air fossil bone assemblages has been used as evidence of attritional accumulation (Potts, 1986; Behrensmeyer, 1991). In accordance with these methods, therefore, we assumed in the present study that bones of the same level showing great variation in weathering conditions reflect different time exposures to the cave atmosphere. Short periods of exposure correspond to a low stage of weathering, whereas more weathered remains testify to longer periods of exposure and probably point to specimens deposited earlier.

According to a study by Díez et al. (1999) on the Aurora Stratum (Atapuerca, Spain), bone surface damage referable to subaerial weathering at the P10 site was considered as evidence of a direct connection between the cave and the open environment. The stages of weathering are defined herein by taking into account both the effects of physical agents, such as variation in humidity and temperature, and the results of burial in a cave environment, such as desquamation. In particular, changes in wetness and exposure to the cave atmosphere cause cracking of bone surfaces (Díez et al., 1999; Kos, 2003) that is often associated with flaking. In this case, flaking comprises delamination of the outer compact bone layer into long, thin flakes that have one or more sides still attached to the bones; flaking becomes deeper and more extensive with an increase in the degree of weathering. In addition, the interaction between bones and the highly alkaline sediments in the cave environment causes desquamation, a peculiar type of surface exfoliation or detachment of a layer of scaly fragments in the outer bone layers (Fernández-Jalvo, 1996; Fernández-Jalvo et al., 1998, 2002; Díez et al., 1999). Variations in weathering stages on a single bone or on a single fossiliferous layer provide important evidence of local depositional history. Differential weathering stages for the upside (MWS: maximum weathering stage) and the downside (FWS: flipside weathering stage) bone surfaces were examined in SU7 bones in order to estimate assemblage stability before burial (after Byers, 2002). Generally, bones with advanced MWS (stage 2 or more) and low FWS (stage $0-1$ ) were subjected to little or no movement before burial and thus indicate stability; on the contrary, bones with advanced stages of both MWS and FWS were moved before burial and represent instability of the assemblage (Byers, 2002).

\section{Taphorecords}

Based of our study of bone surface modifications of the fossil remains from SU7, we introduce the concept of taphorecord, borrowed from invertebrate taphonomy, into macrovertebrate taphonomy. According to the original definition (Fernández-López, 1987) a taphorecord is a paleontological unit comprising a fossil or a group of fossils characterized by one or more features resulting from taphonomic alteration. The term taphorecord does not have any stratigraphic or chronological meaning; nevertheless, recognition of taphorecords may allow the establishment of topological (relative temporal) order and sequences among older and younger fossil assemblages or specimens. In the present paper, taphorecords are applied using the original definition, and their local meaning is particularly stressed because the assemblages come from a single restricted karst structure. The set of taphorecords present within each stratigraphic level is identified as a fossil assemblage. Every fossil assemblage is characterized by a relative abundance of taphorecords, although not all of the identified taphorecords are necessarily present within the same level and the same taphorecord may be encountered at different levels.

\section{Transport Mechanism and Accumulation of Bones}

Transport is one of the most important processes that can affect bones in open-air and karst environments. Both physical and biological mechanisms are involved in accumulation or dispersal of fossil remains

TABLE 2-Weathering stages observed in Sedimentary Unit 7 compared with Behrensmeyer's stages (1978).

\begin{tabular}{|c|c|c|}
\hline \multicolumn{2}{|r|}{ Behrensmeyer (1978) } & P10 site, SU 7 (present work) \\
\hline Stage & Description & Description \\
\hline 0 & No modifications; usually bones are still greasy. & Undamaged, with no visible cracks. \\
\hline 1 & $\begin{array}{l}\text { Cracking parallel to fiber structures; articular surfaces may } \\
\text { present mosaic cracking. }\end{array}$ & $\begin{array}{l}\text { Very superficial longitudinal cracks often associated with Fe-Mn oxidation; splitting of the } \\
\text { shafts of limb bones and mosaic cracks on articular surfaces. }\end{array}$ \\
\hline 2 & Concentric flaking usually associated with cracks. & More extensive splitting, flaking of the outer bone surfaces. Slight desquamation. \\
\hline 3 & $\begin{array}{l}\text { Rough homogeneously altered compact bone resulting in fibrous } \\
\text { texture; weathering do not penetrate deeper than } 1.5 \mathrm{~mm} .\end{array}$ & $\begin{array}{l}\text { Extensive flaking resulting in rough and fibrous aspect; loss of deep portions or flakes of } \\
\text { bones. More extensive desquamation. }\end{array}$ \\
\hline 4 & $\begin{array}{l}\text { Bone surface is coarsely fibrous and rough; weathering } \\
\text { penetrates into inner cavities. }\end{array}$ & More extensive and deeper flaking, bone severely deteriorated, deep desquamation. \\
\hline 5 & Bone falling apart in situ, with large splinters lying around. & Bone falling apart in situ. \\
\hline
\end{tabular}


in caves. Physical transport includes gravity and water currents, whereas biological mechanisms include two possible cases: (1) active systems, called allopod transport agents (Brain, 1981) or biotic allochthonous processes (Simms, 1994), in which predators and scavengers collect bones in dens or caves; and (2) autecological behaviors, i.e., autopod transport mechanisms (Brain, 1981) or abiotic allochthonous processes (Simms, 1994), in which animals either fall into the karst system by accident or enter the cave in search of shelter and die inside. Transport may be analyzed by two effects on bone deposition, i.e., sorting and winnowing of bones according to different transport potential and orientation of long bone axes in the direction of current.

Voorhies' approach (Voorhies, 1969; Behrensmeyer, 1975) was used to establish bone susceptibility to transport in SU7 assemblages. For the first time, Voorhies (1969) documented bone transport under controlled conditions in laboratory flumes and obtained three basic categories with different transport potential. Group I contains the most easily transported bones and Group III those most resistant to transport; transitional groups (Groups I/II and II/III) with intermediate features were also documented. Voorhies' methods, which were based on disarticulated skeletons of sheep and coyotes, were integrated into the present paper along with those of Behrensmeyer (1975) who used bones of different-sized recent animals to display how size, shape, and especially bone density affect transport potential under the same experimental conditions. She noted three main kinds of assemblages (along with transitional cases), including undisturbed (present in Groups I, II, and III), winnowed, and lag; the last two kinds occur mainly in Groups II and III, respectively (Behrensmeyer, 1975).

The proportion of different Voorhies Groups within the same fossil assemblage provides information about the sorting and proximity of fossils to the original site of accumulation (Behrensmeyer, 1975; Coombs and Coombs, 1997). Voorhies Groups cannot be applied to plurispecific taxonomic assemblages without considering shape and density of bones (Behrensmeyer, 1975), because skeletal elements of different taxa respond in different ways to transport, and sometimes homologous elements from different taxa are assigned to different Voorhies Groups. For this reason, the Voorhies Group analysis on the three levels of the SU7 was based only on Axis eurygonos and Hystrix refossa remains, the most common taxa in the assemblages. We analyzed 129 bones from fossil assemblage 7a, 92 from $7 \mathrm{~b}$, and 10 from 7c for A. eurygonos, and 29 bones from fossil assemblage 7a, 23 from $7 \mathrm{~b}$, and 5 from $7 \mathrm{c}$ for $H$. refossa. The bones of these two species were assigned to different transport groups, applying Voorhies' (1969) and Behrensmeyer's (1975) criteria on Reduncini (Bovidae, Hyppotraginae) and the dispersal potential of Ovis bones, on the basis of comparable dimensions to the taxa used in these earlier studies. Axis eurygonos from the Pirro Nord site was a small member of the Cervidae that was slightly smaller than the recent deer taxon, Dama dama dama (Pfeiffer, 1999); H. refossa was generally larger than extant H. cristata (Rook and Sardella, 2005). The variations in relative frequency of Voorhies Groups among fossil assemblages reflect different processes operating in the depositional environment of each assemblage, e.g., current velocity and bottom conditions, but also preburial processes affecting element availability. Furthermore, the presence of different states of preservation, the anatomical connection of bones, and the presence of juvenile individuals may also influence transport potential of various elements (Coard and Dennell, 1995; Coard, 1999; Kaufmann et al., 2010).

Orientation of bones reflects the influence of hydraulic transport on the bone assemblages and allows for inferences about the accumulation agents. In strong currents, long bones usually orient parallel to the current with the heavier end located upstream, whereas in shallow water or weak currents bones are not completely submerged and orient perpendicular to the flow direction and roll downstream around the shaft (Voorhies, 1969; Behrensmeyer, 1975).

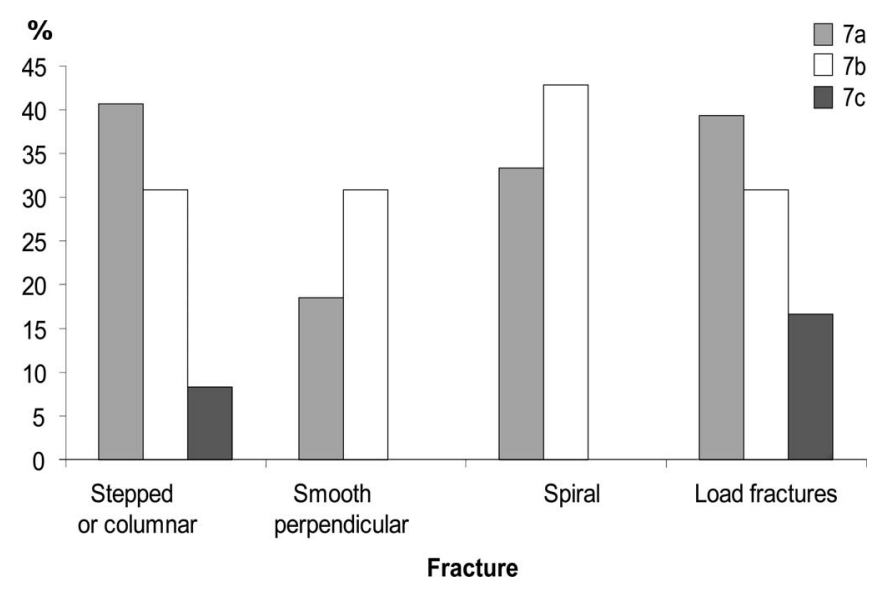

FIGURE 3-Degrees of fracturing in the three levels of Sedimentary Unit 7, Pirro 10 site.

\section{RESULTS}

Skeletal elements of the entire SU7 assemblage are well preserved. The constant sedimentary infilling of porosities and nutrient foramina indicates that the elements were completely lacking in soft tissue at the time of burial (Arribas and Palmqvist, 1998; Rustioni and Mazza, 2001). Generally, skeletal remains from SU7 are fully disarticulated, but specimens in anatomical connection are present in levels $7 \mathrm{a}$ and $7 \mathrm{c}$, and bones clearly pertaining to the same individual were found in different squares of level $7 \mathrm{~b}$ (associated but dispersed elements of Behrensmeyer, 1991) or in close proximity within level 7a (disarticulated but associated elements of Behrensmeyer, 1991). The three cases of residual articulation include metacarpals IV-V of $H$. refossa in 7c and two sets of $A$. eurygonos lumbar vertebrae in 7a; vertebrae are the last skeletal elements to become disarticulated by normal decay processes in an exposed carcass (Behrensmeyer, 1975; Hill and Behrensmeyer, 1984). With regard to associated but dispersed bones, two radii (right and left) and one ulna (left) of Megantereon whitei were found in contiguous squares in level $7 \mathrm{~b}$; disarticulated but associated bones were represented by two scapulae (right and left) and one humerus (left) of A. eurygonos in level $7 \mathrm{a}$.

\section{Bone Surface Modification}

The majority of bones in SU7 are complete (90\% of complete long bones in $7 \mathrm{a} ; 92 \%$ in $7 \mathrm{~b} ; 92 \%$ in $7 \mathrm{c}$ ) as well as vertebrae, scapulae, and ribs (disregarding any damage produced during excavation); however, different types of fracture were recognized (Fig. 3). In all investigated levels, some fractures are related to in situ breakage (Fig. 3), where fragments of the same bone were found in contact or slightly shifted, and incomplete fractures and deformations of bones were observed. This type of breakage is clearly related to load and compaction of sediments and increases with depth; the presence of shifted fragments is related to only slight displacement after burial (Villa and Mahieu, 1991; Díez et al., 1999).

Spiral fractures observed in $7 \mathrm{a}$ and $7 \mathrm{~b}$ are rarely correlated with recognizable tooth perforations and/or gnawing of the epiphysis; only four bones from $7 \mathrm{a}$, six bones in $7 \mathrm{~b}$, and one bone in $7 \mathrm{c}$ display identifiable tooth marks such as oval to subcircular pits or wide linear marks. The scarcity of tooth marks and breakage on bones, along with the presence of large numbers of carnivores in the SU7 fossil assemblages (Table 1) do not allow us to clearly identify the animal that produced such tooth marks and gnawing.

Pitting is documented on six bones from $7 \mathrm{a}$ and three from $7 \mathrm{~b}$. In these levels, both isolated subcircular cavities and large irregular depressions commonly occur on the same bone and are randomly 


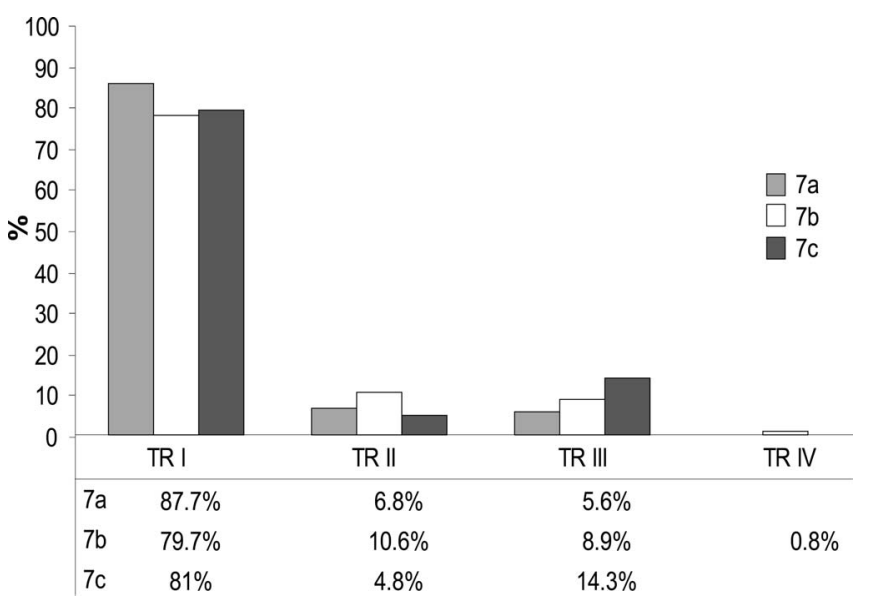

FIGURE 4-Relative abundances of taphorecords (TR I-IV) in the three SU7 fossil assemblages (levels 7a-7c).

distributed on the bone surface, although only one of these morphologies is recorded on some remains. These pitting morphologies appear to be related to higher stages of weathering (stage 2 or more) and probably result from leaching due to drip water and interaction with cave water (Kos, 2003).

Usually the degree of abrasion on elements is very low in all of SU7; no surface polishing was observed and prominent edges of bones are intact (except in TR II, see below). Only one bone in 7a, two in 7b, and one in $7 \mathrm{c}$ display rough surfaces referable to abrasion. Abrasion in these bones is linked to higher weathering states (stages 2-3 or more).

\section{Oxidation, Coating, and Coloring of Bones}

All the observed samples from SU7 display manganese coatings (89\% of colored remains in 7a; $97 \%$ in $7 \mathrm{~b}$, and $95 \%$ in $7 \mathrm{c}$ ) including longitudinal black lines associated with surficial bone cracks, local dendritic deposits, or more extensive coats. These features are often mixed and not localized on a specific area of bone surface; no relationships between Mn-oxide distribution and stratigraphic level or other taphonomic features were observed. Usually, the downside surface of the bones, e.g., the side in contact with the sediment surface at the time of deposition, is yellow to orange and darker than the upper side, even though some specimens display an almost homogeneous yellow to light brown color. In both cases, two different kinds of surficial coatings were sometimes observed mixed together, i.e., (1) subcircular centimetric brown spots of unknown origin and (2) irregular brown to orange bands resulting from interaction between bones and groundwater. Such colorings may derive from postburial oxidation processes on light Fe coatings on bones induced by a local discontinuity of sediment texture or by percolating water within the sediments.

\section{Weathering Stages and Bone Taphorecords}

In all of the fossil remains from SU7, weathering varies from undamaged bones or bones with very surficial narrow cracks, often associated with Fe-Mn oxidation and parallel to the fiber structures (stage 1, Table 2), to more extensive damage with wider and deeper fissures associated with flaking of bone surfaces and desquamation (stages 2-4, Table 2). As noted by Behrensmeyer (1978, 1991) and Lyman and Fox (1989) in open-air sites, bones from the same carcass may display different weathering stages due to skeletal element, taxon, and/or microenvironmental conditions. In the SU7 levels, paired bones of the same individual (e.g., right and left radii and left ulna of $M$. withei) show homogeneous weathering stages, whereas the same skeletal element from different individuals (e.g., tibiae of A. eurygonos) displays strong differences in weathering degree varying on a specimen by specimen basis. In addition, no correlation between weathering stage and ontogenetic development has been observed.

The presence of different degrees of weathering in SU7 fossil assemblages, together with abrasion and coloring of bones, was particularly significant in the characterization of taphorecords, whereas the presence of tooth marks, bone fracturing, or manganese coatings was not useful because they are common and recur in different states of preservation. Taking into account these assumptions, all the skeletal elements from the three levels of SU7 were separated into four taphonomic categories or taphorecords (TR); the frequency of taphorecords in each of the fossil assemblages is summarized in Figure 4 and examples of each type shown in Figure 5:

1. TR I: well-preserved specimens with a very low stage of weathering. Both maximum weathering stage (MWS) and flipside weathering stage (FWS) are either 0 or 1, being either homogeneous on the entire bone surface or with MWS slightly higher. No abrasion surfaces are observed; usually, coloring is homogeneous or the downside of bones is yellow orange and darker than the upside (Figs. 5A-B).

2. TR II: well-preserved specimens with different stages of MWS and FWS. FWS varies from $0-1$ while MWS may reach stage 2 of weathering. Usually the prominent edges of the bones are more weathered. Abrasion and coloring are similar to those described in TR I (Figs. 5C-E, G).

3. TR III: high stage of weathering (stage 3 or more) both in MWS and in FWS, and both sides are quite homogeneous. Bones are slightly abraded and pitting is present. Coloring is generally homogeneous and slightly darker than TR I and II (Figs. 5F, J-K).

4. TR IV: high stage of weathering (stage 3 or more) both in MWS and in FWS, but with FWS more weathered than MWS. This situation is unusual in that the side with a higher degree of weathering is the one in contact with the cave floor (FWS). Abrasion and coloring are similar to those described in TR III. This taphorecord is represented only by an adult left mandible of A. eurygonos from level 7b (PU 124587; Figs. 5H-I).

\section{Sorting and Orientation of Bones}

Data recorded for A. eurygonos in SU7 indicate that almost all Voorhies Groups are well represented with a predominance of Group I; Group I/II is missing from level 7c and Group II/III from all levels. For H. refossa, all Voorhies Groups are largely represented; Group I is the most prevalent, but Groups I/II and II/III are present except in level 7c (Fig. 6). In both taxa, the absence of ribs and depletion of vertebrae, which are strongly fractured and often indeterminable, results in an underrepresentation of Group I/II for A. eurygonos and of Group I for H. refossa.

Analysis of the spatial distribution of remains within the $7 \mathrm{a}$ and $7 \mathrm{~b}$ levels suggests some hypotheses about the depositional environment in which the bone assemblages were accumulated. Level $7 \mathrm{c}$ has not been considered because the low number of measured remains (15) is not statistically meaningful. Starting from the lowest level (7a), variation in current circulation toward the upper part of the SU7 is documented. The depositional style is strongly influenced by the presence of a flowstone concretionary structure associated with cemented breccia (Pavia et al., 2011); this structure is sufficiently developed to generate obstacle shadows as flow-aligned features that form due to scouring and deposition which extends downstream of the obstacle (Fig. 7). As demonstrated in the case of circular and impermeable obstructions such as trees or piers, current flow velocity decreases in front of the obstacle and friction with the bed material causes a downward pressure gradient 


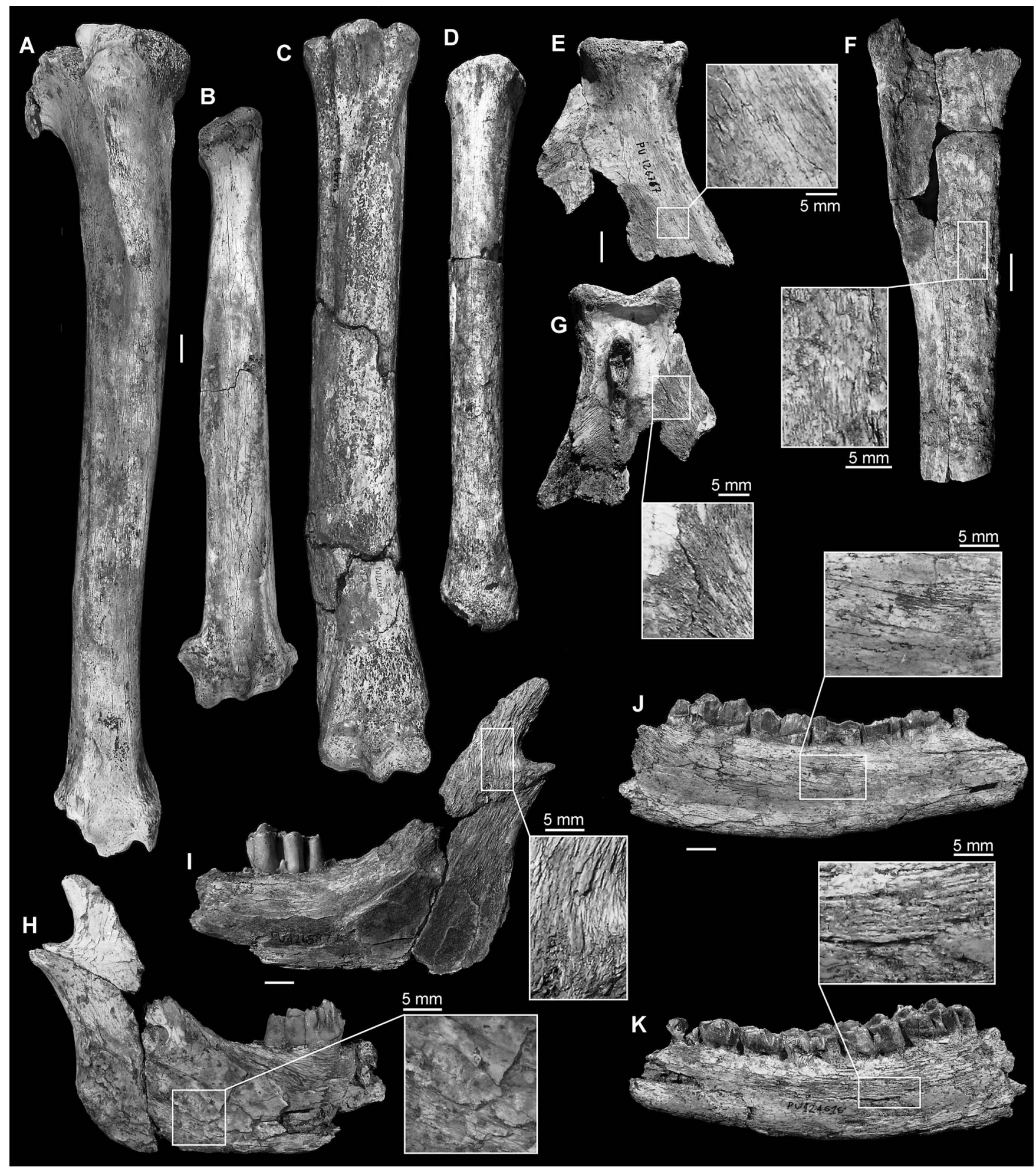

FIGURE 5-Representative fossil remains from SU7 and their classification as taphorecords (see also Tables 1-2). A) Axis eurygonos right tibia from level 7b, TR I (MWS=FWS=0-1); PU 125735. B) Megantereon whitei left radius from level 7b, TR I (MWS=FWS=0-1); PU 124302. C) Equus altidens right metatarsal from level 7b, TR II (MWS=1; FWS=2) showing load deformation; PU 124408. D) A. eurygonos right metacarpal from level 7b, TR II (proximal epiphysis shows $\mathrm{W}=1 ;$ distal one, $\mathrm{W}=2$ ); PU 124266. E, G) Xenocyon lycaonoides left scapula from level 7a, TR II (MWS = 1; FWS = 2); PU 126767. F) A. eurygonos left tibia from level 7c, TR III (MWS = FWS = 3); PU 124450. H-I) A. eurygonos left emimandible from level 7b, TR IV (MWS = 3; FWS = 3-4); PU 124587. J-K) A. eurygonos, left emimandible from level 7c, TR III (MWS = 3; FWS $=2$ ); PU 124616. All scale bars $=1 \mathrm{~cm}$, unless indicated otherwise.

associated with horseshoe vortices around the front and sides of the obstruction; rotary or multidirectional flow associated with wake vortices occur on the lee side of the obstacle (Karcz, 1968; Rygel et al., 2004).
The direction of bones in levels $7 \mathrm{a}$ and $7 \mathrm{~b}$ is shown on a rose diagram (Fig. 7), which includes only specimens $>5 \mathrm{~cm}$. In level $7 \mathrm{a}$, a prevailing (37\%) NNW-SSE orientation and a minor WNW-ESE (25\%) direction are observed. This could be explained by the presence of turbulent flow 


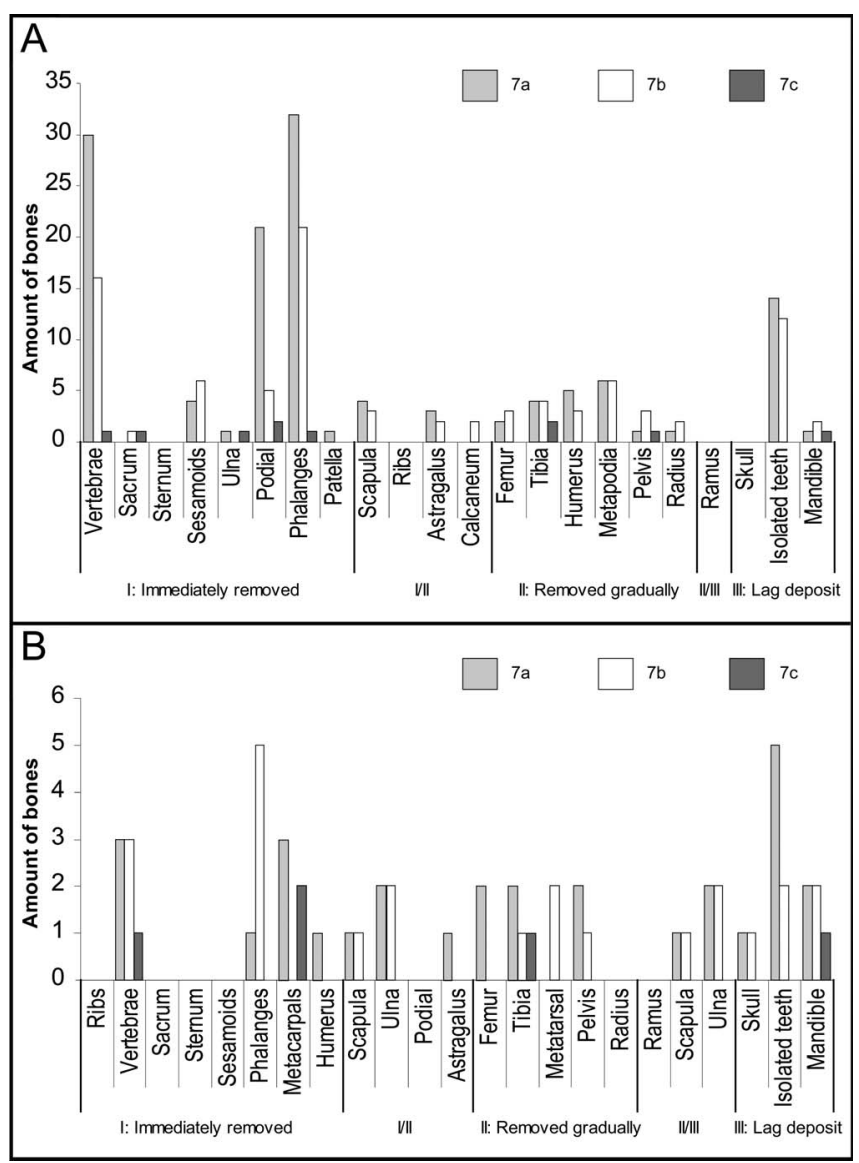

FIGURE 6-Transport groups of various skeletal elements in SU7 obtained by integrating the methods of Voorhies (1969) and Behrensmeyer (1975). A) Axis eurygonos. B) Hystrix refossa.

acting on the lee side of the concretionary structure which resulted in two preferred orientations of the bones (Fig. 7B). An episodic turbulent flow could also be hypothesized to explain groups of bones amassing along the cave wall in squares G13-G15.

For level 7b, we can hypothesize the presence of a water current orienting bones with the long axis parallel to the cave boundary as suggested by the preferential alignment of the remains; $37 \%$ of the elements show a WNW-ESE preferred orientation. Heavier ends are generally oriented WNW, especially those of tibiae, which are considered the most indicative bones for paleocurrent directions (Voorhies, 1969). With these data, we envisage a stream direction from WNW to ESE. Bones lay on a gentle slope $\left(\sim 15^{\circ}\right)$ due to the presence of the flowstone structure controlling bone transport and deposition. A stream current from the WNW matches the obstacle and would deposit elements on its lee side (Fig. 7C). The low degree of sorting and the presence of bone orientation suggest deposition by water flows subject to short-term fluctuations, whereas the presence of bones with different states of preservation points to switching between erosional and depositional regimes, broken up by periods of no sedimentation.

\section{Element Quantification}

The concept of taphorecord and its chronological implications have never previously been used in element quantification. In the current study the presence of different taphorecords in the same fossil assemblage provides data about the relative temporal sequence of deposition. The presence of time averaging places additional value on the significance of both NISP and MNI (Tables 3-5). If taphorecords were not taken into account, the results would have underestimated the minimum number of individuals; with taphorecords, it is possible to refer bones to the same individual (e.g., the right and left tibia of $A$. eurygonos), even though they are heterochronous elements. For example, in the case of Axis eurygonos in assemblage 7b, if we assume that all the samples are synchronous elements, without considering their different preservation features, we obtain a total of three adult individuals and one subadult (Table 4). If we apply the taphorecord method and also consider diachronous or heterochronous elements, we obtain a higher number of individuals, namely five adults and one subadult in the preserved and excavated sediment.

In the case of expected versus observed numbers of bones of $A$. eurygonos, due to a higher abundance of limb bones (mainly carpal and tarsal) and phalanges (Fig. 8), there was an under-representation of all the skeletal elements within the three layers of SU7; the number of remains is particularly low for assemblage 7c. This under-representation of elements is the result of different processes linked to the depositional environment and to postdepositional events due to the modification and erosion of the outcrop.

\section{DISCUSSION}

\section{Taphorecords}

The low stage of weathering of TR I is indicative of short-term exposure on the cave surface related to rapid and complete burial. The differences in weathering stages recorded on the upper and lower sides of bones typical of TR II are caused by incomplete burial; indeed the prominent edges continued to be exposed and became more weathered. This implies an episode of rapid sedimentation after transport that covered the bones of TR I completely and those of TR II partially, followed by a period of surface stability resulting in the removal of the exposed bone surfaces. Bones belonging to TR I and TR II are coeval with each other and with the encasing matrix, reflecting a single depositional event.

The high stages of weathering recorded in TR III (MWS = FWS) could be explained in two different ways: taphogenic production in different areas of the karst system or a different period of exposure. In both cases, the highly homogeneous weathering on MWS and FWS testifies to a longer period of exposure which allowed for weathering of the exposed side (MWS), overturning of bones on the cave floor, and a new phase of exposure and weathering of the other side of the bones (FWS). The state of preservation of TR III elements led us to consider a different period of surface exposure of the bones as the most probable hypothesis; from this point of view, TR III can be considered heterochronous (probably older) compared to TR I and TR II. Generally, the elements grouped in TR I-III might be defined as resedimented bones (i.e., bones displaced on the sedimentary surface before burial, sensu Fernández-López, 1991, 2007, 2011), even though the presence of slight abrasion and pitting in TR III also suggests iterative exposure of bones due to successive exhumations on the depositional floor, i.e., reworking (sensu Potts, 1986; Byers, 2002; Kos, 2003) or reelaboration (sensu FernándezLópez, 1991, 2007, 2011; Fernandez-Jalvo et al., 2002; Martire and Torta, 2000; Reolid, 2008).

The terms reelaborated and reworked are not synonyms in a taphonomic context. Conversely, the terms reworked or rehandled are equivalent to the French word remanié; these are stratigraphic terms (Jackson, 1997) applied in geology to fragments or entities derived from older materials, and thus also to fossils (regarded as sedimentary particles) that have been removed from or washed out of an older bed and deposited in a new one. In this context, reworked fossil is also a stratigraphic term (Jackson, 1997) and assumes a chronostratigraphic meaning because the fossils were derived from rocks of one age, eroded, transported, and redeposited in younger sediments. In contrast, the 


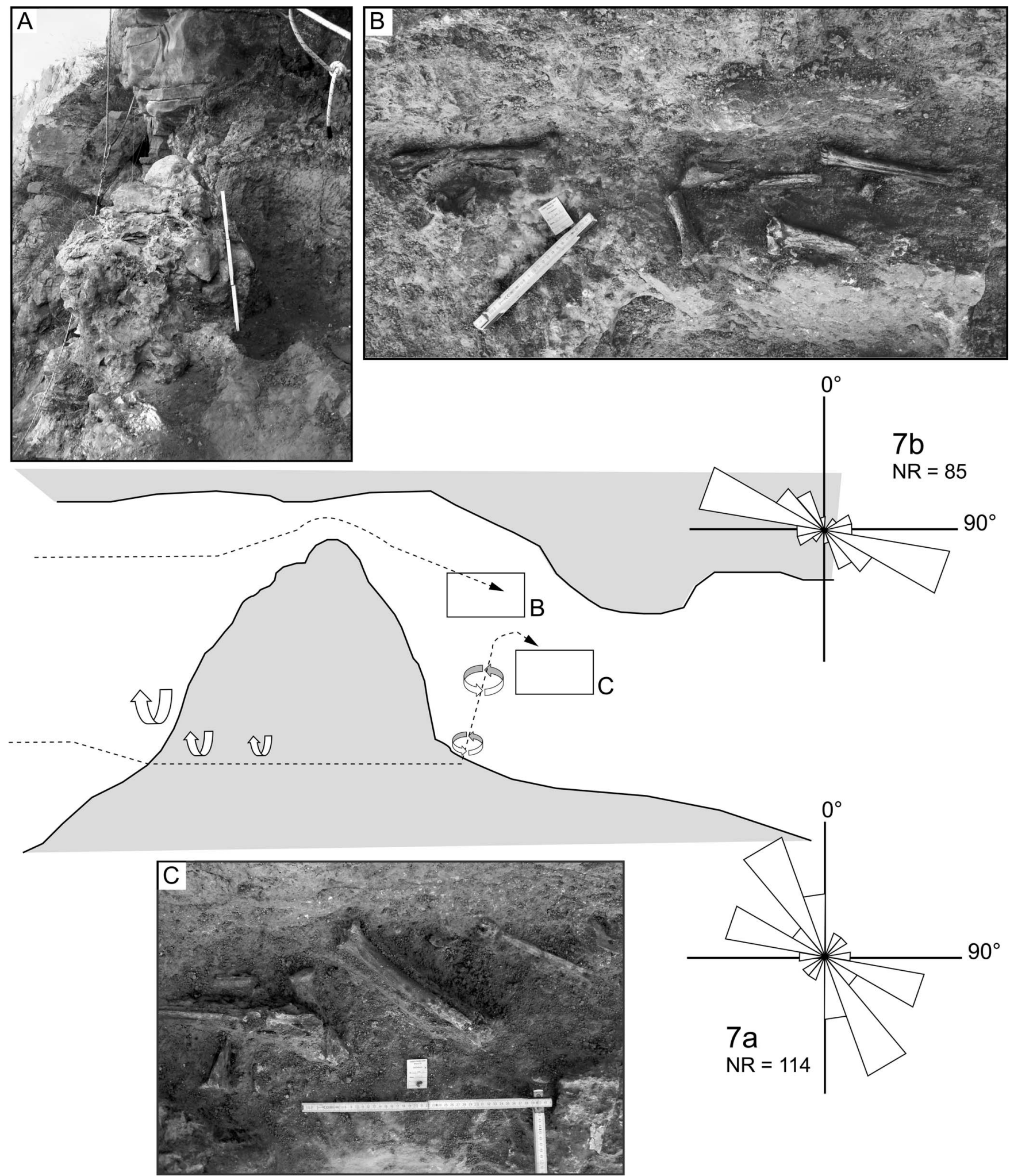

FIGURE 7-Concretionary structure occurring in squares F10-11 of the Pirro 10 site and its effect on bone distribution in SU7. Dotted arrows indicate main flow direction; broad arrows show areas of turbulent flow due to the presence of the concretion. A) Concretionary body; B) Spatial distribution of bones in level $7 \mathrm{~b}$ and relative rose diagram (below); C) Spatial distribution of bones in level 7a with relative rose diagram (right). NR = number of remains.

terms remobilized or reworked (as antonyms of accumulated), when used in a taphonomic sense, mean resedimented or reelaborated and point to the relationships between fossils and their sedimentary matrix. Reworked fossils can be subdivided into two preservational categories: resedimented and reelaborated fossils.
Taphonomic resedimentation means displacement along the sedimentary surface prior to burial, whereas taphonomic reelaboration refers to the exhumation and displacement of preserved elements that were previously buried. From a stratigraphic point of view, every fossil included in a lithoclast is a reworked or derived fossil, whereas from a 
TABLE 3-Element quantification of vertebrate remains from level 7a, Sedimentary Unit 7. NISP = number of identified specimens; MNI = minimum number of individuals; * = subadult remains; bold $=$ TR III elements

\begin{tabular}{|c|c|c|c|c|c|c|c|c|c|c|c|c|c|c|}
\hline \multirow[b]{2}{*}{$7 \mathrm{a}$} & \multicolumn{2}{|c|}{ Hystrix refossa } & \multicolumn{2}{|c|}{ Ursus etruscus } & \multicolumn{2}{|c|}{$\begin{array}{c}\text { Canis } \\
\text { mosbachensis }\end{array}$} & \multicolumn{2}{|c|}{$\begin{array}{c}\text { Xenocyon } \\
\text { lycaonoides }\end{array}$} & \multicolumn{2}{|c|}{ Vulpes alopecoides } & \multicolumn{2}{|c|}{$\begin{array}{l}\text { Pachycrocuta } \\
\text { brevirostris }\end{array}$} & \multicolumn{2}{|c|}{ Megantereon whitei } \\
\hline & NISP & MNI & NISP & MNI & NISP & MNI & NISP & MNI & NISP & MNI & NISP & MNI & NISP & MNI \\
\hline \multicolumn{14}{|l|}{ Maxilla } & \\
\hline Mandibula & $1 *+1$ & $1 *+1$ & & & & & 1 & 1 & & & & & & \\
\hline Isolated teeth & 13 & 4 & $1+2$ & $1+1$ & 4 & 1 & 4 & 1 & & & 1 & 1 & & \\
\hline Scapula & 1 & 1 & & & & & 1 & 1 & & & & & & \\
\hline Humerus & 1 & 1 & & & 1 & 1 & & & & & & & & \\
\hline Radius & & & & & 1 & 1 & & & & & & & & \\
\hline Ulna & $2 *$ & $1^{*}$ & & & & & 1 & 1 & & & & & & \\
\hline Carpal & & & & & & & 1 & 1 & & & & & & \\
\hline Matacarpal & 3 & 1 & & & 1 & 1 & & & & & & & & \\
\hline Pelvis & 2 & 2 & & & & & & & & & & & & \\
\hline Femur & $1^{*+1}$ & $1 *+1$ & & & & & & & & & & & & \\
\hline Tibia/fibula & $1+1 *+1$ & $1+1 *+1$ & & & & & & & & & & & & \\
\hline Tarsal & 1 & 1 & & & 1 & 1 & 2 & 2 & & & & & & \\
\hline Metatarsal & & & & & & & & & & & 1 & 1 & & \\
\hline Metapodial & & & & & & & 1 & 1 & & & & & & \\
\hline \multicolumn{15}{|l|}{ Ribs } \\
\hline Atlas & & & & & 1 & 1 & & & & & & & & \\
\hline Axis & & & 1 & 1 & & & & & & & & & & \\
\hline \multicolumn{15}{|l|}{ Cervical } \\
\hline Thoracic & 1 & 1 & & & 1 & 1 & 1 & 1 & & & & & & \\
\hline Lumbar & 1 & 1 & & & & & & & & & & & & \\
\hline \multicolumn{15}{|l|}{ Sacral } \\
\hline Caudal & 1 & 1 & & & & & & & & & & & & \\
\hline Phalange I & 1 & 1 & & & & & 1 & 1 & & & 1 & 1 & & \\
\hline Phalange II & & & 1 & 1 & 1 & 1 & & & & & & & & \\
\hline Phalange III & & & 1 & 1 & & & & & & & & & & \\
\hline Undeterminate & & & & & & & & & & & & & & \\
\hline Total & $26+5^{*}+3$ & $4+1 *+1$ & $4+2$ & $1+1$ & $10+1$ & $1+\mathbf{1}$ & 13 & 2 & & & 3 & 1 & & \\
\hline
\end{tabular}

taphonomic point of view it can be identified as an accumulated, resedimented, or reelaborated fossil in relation to the sedimentary matrix or the enclosing rock (Fernández-López, 1991, 2007, 2011).

TR IV illustrates a high degree of weathering, with the side in contact with the cave floor presenting a higher degree of weathering. This taphorecord is interpreted as composed of a reelaborated element that was exhumed and displaced from previous deposits within the gallery or from separate sites within the karst system. According to this interpretation, bones belonging to TR III-IV must be considered and counted separately from those of TR I-II because they clearly experienced different biostratinomic histories and taphonomically were produced earlier.

The mixing of elements belonging to different taphonomic categories (TR I-IV) within the same fossiliferous level suggests a complex sedimentary history in the P10 karst structure resulting from either synchronous bone modification occurring in different areas with different environmental conditions (e.g., strong variations in temperature or moisture) or from diachronous (at a different time and place) or heterochronous (of different duration) assemblages. In any of these three possibilities, long-term or attritional accumulation (Behrensmeyer, 1991) before burial would have been involved. The occurrence of a single reelaborated element in this complex fossil assemblage corroborates the heterochronous and condensed character of these assemblages (Gómez and Fernández-López, 1994).

\section{Taphonomic Interpretations}

Destruction of the original morphology of the Pirro 10 gallery and work in progress in the quarry do not facilitate a depositional or taphonomic interpretation. The taphonomic data analyzed here, however, allow us to suggest a plausible reconstruction of the depositional history of the Sedimentary Unit 7 (SU7) bone layers. In particular, analyses of the various states of preservation, element quantification, and observations on sorting and orientation of bones provide significant information. As demonstrated by the sedimentologic and stratigraphic analyses, the P10 gallery sedimentary infilling is linked to groundwater circulation that moved sediments and bones within the karst system (Pavia et al., 2011). Taphonomic features of SU7 fossil remains are homogeneous within the three fossiliferous levels, suggesting a similar taphonomic history. For this reason, a common depositional model, subdivided into three main phases for each level, is proposed for the bones in SU7 (Fig. 9).

Phase 1: Accumulation (Figs. 9A-B).- - The low number of tooth marks and breakage in the fossils precludes predation as the main cause of the accumulation; autopod transport mechanisms are the most probable. The presence of weathering processes on the remains due to wetness and temperature fluctuations may be related to an accumulation area near a cave entrance, although considering the present-day condition of the Pirro 10 site, it is hard to determine the direction of this connection. Nevertheless, high stages of weathering together with rare tooth marks and trampling documented in SU5 (Pavia et al., 2011) suggest a good connection with the open air at least in the earliest phases of cavity infilling.

The presence in SU7 of bones characterized by different weathering and disarticulation features can be explained by a long-term accumulation involving the cave system. Bones with a higher degree of disarticulation and weathering are referable to animals that entered the cave system earlier, whereas carcasses of animals that entered later were partially disarticulated and less affected by weathering damages. In levels $7 \mathrm{a}$ and $7 \mathrm{c}$, the presence of metacarpals and vertebrae in anatomical connection testifies to an exposure time that was not long enough for complete disarticulation, probably because transport of vertebrate remains began at this stage.

Phase 2: Transport (Fig. 9C).-The SU7 fossil assemblages contain remains that underwent different depositional and postdepositional 
TABLE 3-Extended.

\begin{tabular}{|c|c|c|c|c|c|c|c|c|c|c|c|c|c|c|}
\hline \multicolumn{2}{|c|}{ Homotherium latidens } & \multicolumn{2}{|c|}{$\begin{array}{c}\text { Panthera } \\
\text { gombaszoegensis }\end{array}$} & \multicolumn{2}{|c|}{ Equus altidens } & \multicolumn{2}{|c|}{ Axis eurygonos } & \multicolumn{2}{|c|}{$\begin{array}{l}\text { Stephanorhinus cf. } \\
\text { hundsheimensis }\end{array}$} & \multicolumn{2}{|c|}{$\begin{array}{c}\text { Bison (Eobison) } \\
\text { degiulii }\end{array}$} & \multicolumn{2}{|c|}{$\begin{array}{c}\text { Praemegaceros } \\
\text { obscurus }\end{array}$} & \multirow{2}{*}{$\frac{\text { Indeterminate }}{\text { NISP }}$} \\
\hline NISP & MNI & NISP & MNI & NISP & MNI & NISP & MNI & NISP & MNI & NISP & MNI & NISP & MNI & \\
\hline & & & & & & 6 & 3 & & & & & & & 5 \\
\hline & & & & & & 1 & 1 & & & & & & & \\
\hline & & & & & & 1 & 1 & & & & & & & \\
\hline & & 1 & 1 & 1 & 1 & 14 & 2 & & & & & & & 4 \\
\hline & & & & & & 4 & 3 & & & & & & & 1 \\
\hline & & & & & & $3+1$ & $3+1$ & & & & & & & \\
\hline & & & & & & 1 & 1 & & & & & & & \\
\hline & & & & & & 1 & 1 & & & & & & & \\
\hline & & & & & & 14 & 3 & & & & & & & 1 \\
\hline & & & & & & 1 & 1 & & & & & & & \\
\hline & & & & & & 1 & 1 & & & & & & & 2 \\
\hline & & & & & & $1+1$ & $1+1$ & & & & & & & \\
\hline & & & & & & $3+1^{*}$ & $3+1^{*}$ & & & & & & & \\
\hline \multirow[t]{9}{*}{2} & 1 & 1 & 1 & 1 & 1 & $13+1$ & $3+1$ & & & 1 & 1 & & & \\
\hline & & & & & & $4+1$ & $3+1$ & & & & & & & \\
\hline & & & & 1 & 1 & & & & & & & & & \\
\hline & & & & & & & & & & & & & & 31 \\
\hline & & & & & & $2+1$ & $2+1$ & & & & & & & \\
\hline & & & & & & $10+1 *+1$ & $3+1^{*}$ & & & & & & & 1 \\
\hline & & & & & & $2+6^{*}$ & $1+1^{*}$ & & & & & & & \\
\hline & & 1 & 1 & & & $8+2 *$ & $3+1^{*}$ & & & & & & & 2 \\
\hline & & & & & & & & & & & & & & 2 \\
\hline \multirow[t]{4}{*}{2} & 1 & 1 & 1 & & & $10+1$ & $2+1$ & & & 1 & 1 & & & \\
\hline & & & & & & 10 & 2 & & & & & & & 1 \\
\hline & & & & & & $10+1$ & $2+1$ & & & & & & & \\
\hline & & & & & & & & & & & & & & 7 \\
\hline $2+2$ & $1+1$ & 4 & 1 & 3 & 1 & $119+10^{*}+9$ & $3+1^{*}+1$ & & & 2 & 1 & & & 57 \\
\hline
\end{tabular}

histories. All bones were transported before burial (resedimented elements) and in one case, taphonomic reworking or reelaboration (Fig. 9, gray bone) can be inferred. The original accumulation area was probably located NW with respect to the current P10 location and unfortunately is not yet recognizable.

The study of the orientation and sorting of bones leads us to hypothesize about the intensity of transport processes involving the vertebrate remains. The occurrence of preferential orientation of diaphyses and a low degree of sorting (indicated by the dominance of Voorhies Group I) point to a flow able to move sediments and bones. The presence of Voorhies Groups II and III, however, indicates that the place of disarticulation, where transport processes began to affect bones, was proximal to the area of burial and discovery. The flow was apparently enough to cause preferential orientation of bones but not enough to lead to strong sorting of remains. The final shape of each SU7 level is also influenced by the presence of the concretionary structure in F10-11 squares, which acted as an obstacle shadow and influenced current circulation and the consequent distribution of bones.

Phase 3: Burial (Figs. 9D-E).-Burial affected the bone assemblages after the transport phase. Sedimentation took place and completely or partially covered the vertebrate remains; in the latter case, prominent edges and exposed surfaces exhibit higher degrees of weathering (Fig. 9D). In level 7a, the burial phase is documented by the occurrence of sediment within foramina in bones still in anatomical connection. Here the decomposition of organic matter took place before burial but after transport, otherwise transport would have resulted in disarticulation. Later transport phases can be ruled out because of the presence of these connected bones and of fracturing related to small movements after burial.

Concerning Voorhies Groups, Group I is the most prevalent for both taxa examined. If the dominance of Group I suggests that some kind of transport and selection of bones occurred, then the presence of Groups II and III suggests the proximity of the fossils to the original thanatocoenoses and consequently to the site where transport began to affect the bones. As described above, we suppose that elements were transported after a more or less prolonged exposure to the P10 gallery atmosphere and deposited when and where a mixing of wet (still in anatomical connection), dry, and in some cases highly weathered bones were present. Although the presence of subadult bones and their anatomical connection may suggest a high transport potential for SU7 bones, the mixing of different Voorhies Groups in the same level indicates that the transport was not strong enough to select bones.

In addition, there is a slight incongruity between size of skeletal elements and grain size of the embedding matrix, which is a sandyclayey sediment with scattered carbonate pebbles. According to Behrensmeyer's studies (1975) on recent bones, assemblages dominated by a medium-sized Cervidae such as $A$. eurygonos would be related to coarse to very coarse sands. A lack of hydraulic equivalence between skeletal remains and sediment matrix is further evidence that fossils were not subjected to long-term transport within the P10 gallery.

All of these depositional and postdepositional processes generated a complex fossil assemblage in which different taphorecords are recognizable (Fig. 9E). TR I-II group bones were deposited and buried simultaneously but with a different sedimentary cover, after which they were subjected to different degrees of weathering. The TR III group contains bones that experienced a long sedimentary phase, enough to overturn them on the accumulation surface, as evidenced by homogeneous weathering on MWS and FWS. All of these characteristics can be explained in two different ways. The bones were resedimented and experienced a higher degree of weathering than those of TR I-II, or they were reelaborated from older levels. It must be pointed out that no definitive evidence of reelaboration was observed in 
TABLE 4-Element quantification of vertebrate remains from level $7 \mathrm{~b}$. NISP $=$ number of identified specimens; MNI $=$ minimum number of individuals; $*=$ subadult remains; bold $=$ TR III elements; italics = reelaborated element (TR IV).

\begin{tabular}{|c|c|c|c|c|c|c|c|c|c|c|c|c|c|c|}
\hline \multirow[b]{2}{*}{$7 \mathrm{~b}$} & \multicolumn{2}{|c|}{ Hystrix refossa } & \multicolumn{2}{|c|}{ Ursus etruscus } & \multicolumn{2}{|c|}{$\begin{array}{c}\text { Canis } \\
\text { mosbachensis }\end{array}$} & \multicolumn{2}{|c|}{$\begin{array}{l}\text { Xenocyon } \\
\text { lycaonoides }\end{array}$} & \multicolumn{2}{|c|}{ Vulpes alopecoides } & \multicolumn{2}{|c|}{$\begin{array}{c}\text { Pachycrocuta } \\
\text { brevirostris }\end{array}$} & \multicolumn{2}{|c|}{ Megantereon whitei } \\
\hline & NISP & MNI & NISP & MNI & NISP & MNI & NISP & MNI & NISP & MNI & NISP & MNI & NISP & MNI \\
\hline $\begin{array}{l}\text { Crania-antler } \\
\text { Maxilla }\end{array}$ & 1 & 1 & & & & & & & & & & & & \\
\hline Mandibula & 2 & 2 & & & & & & & & & & & & \\
\hline Isolated teeth & 5 & 1 & $1+1^{*}$ & $1+1^{*}$ & 5 & 1 & 1 & 1 & 1 & 1 & & & & \\
\hline $\begin{array}{l}\text { Scapula } \\
\text { Humerus }\end{array}$ & 1 & 1 & & & & & & & & & & & & \\
\hline Radius & & & & & & & & & & & & & 2 & 1 \\
\hline Ulna & $1+1$ & $1+1$ & 1 & 1 & & & & & & & & & 1 & 1 \\
\hline Carpal & & & $1^{*}$ & $1^{*}$ & & & & & & & 1 & 1 & & \\
\hline Matacarpal & & & & & & & & & & & & & 1 & 1 \\
\hline Pelvis & 1 & 1 & & & & & 1 & 1 & & & & & & \\
\hline Femur & & & & & & & 1 & 1 & & & & & & \\
\hline Tibia/fibula & 1 & 1 & & & & & & & & & & & & \\
\hline Tarsal & & & & & 1 & 1 & & & & & & & & \\
\hline $\begin{array}{l}\text { Metatarsal } \\
\text { Metapodial } \\
\text { Ribs } \\
\text { Atlas }\end{array}$ & 2 & 1 & 1 & 1 & & & & & & & & & & \\
\hline Axis & & & & & & & 1 & 1 & & & & & & \\
\hline $\begin{array}{l}\text { Cervical } \\
\text { Thoracic }\end{array}$ & 2 & 1 & & & & & & & & & & & & \\
\hline $\begin{array}{l}\text { Lumbar } \\
\text { Sacral }\end{array}$ & $1^{*}$ & $1^{*}$ & & & & & & & & & & & & \\
\hline Caudal & & & & & 2 & 1 & & & & & & & & \\
\hline Phalange I & 1 & 1 & 2 & 1 & 1 & 1 & & & & & 1 & 1 & & \\
\hline Phalange II & & & 1 & 1 & & & & & & & & & & \\
\hline $\begin{array}{l}\text { Phalange III } \\
\text { Undeterminate }\end{array}$ & 4 & 1 & 1 & 1 & & & & & & & & & & \\
\hline Total & $21+1 *+1$ & $2+1 *+1$ & $7+2 *$ & $1+1^{*}$ & 9 & 1 & 4 & 1 & 1 & 1 & 2 & 1 & 4 & 1 \\
\hline
\end{tabular}

TABLE 5-Element quantification of vertebrate remains from level 7c. NISP $=$ number of identified specimens; MNI $=$ minimum number of individuals; $*=$ subadult remains; bold $=$ TR III elements.

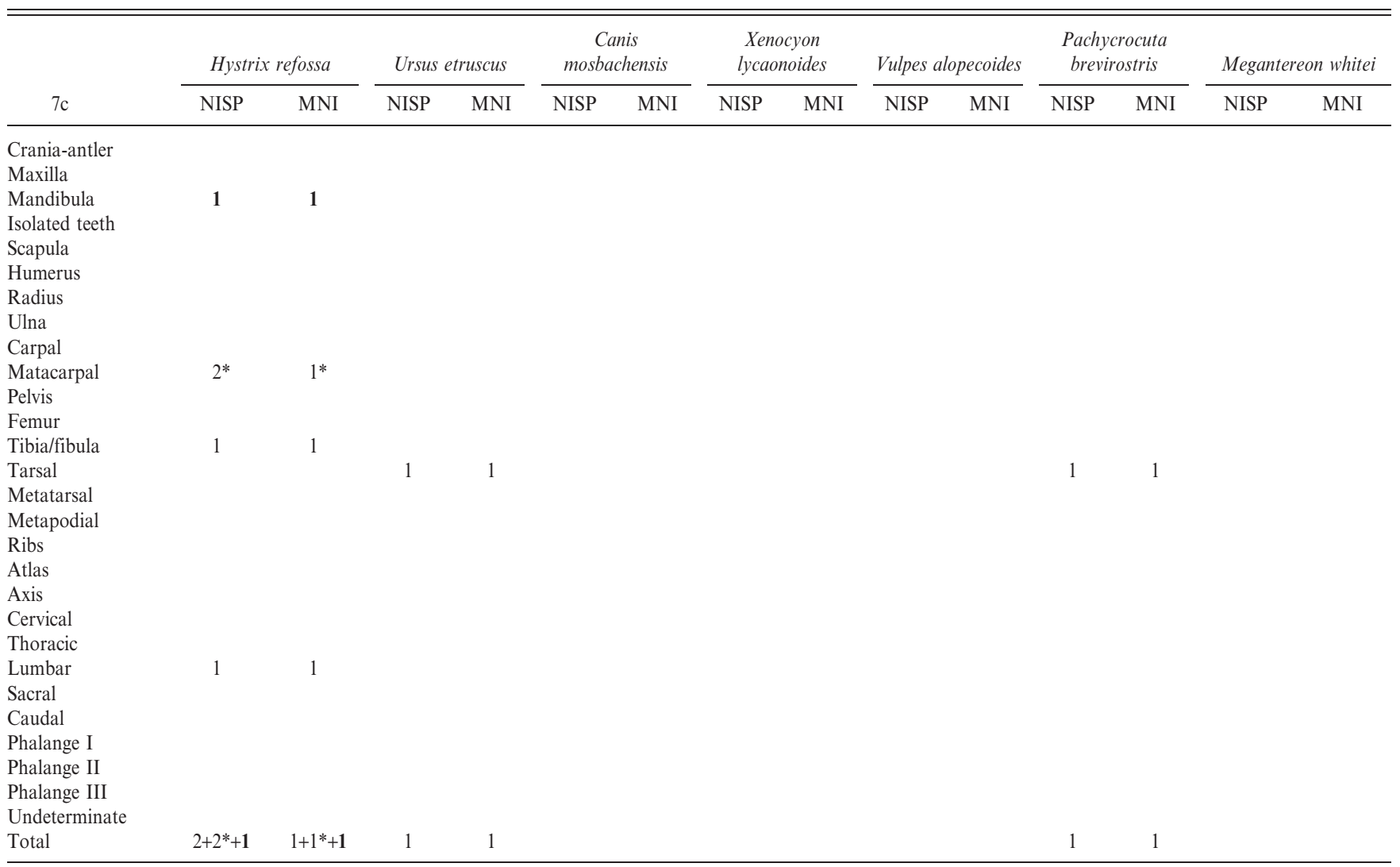


TABLE 4-Extended.

\begin{tabular}{|c|c|c|c|c|c|c|c|c|c|c|c|c|c|c|}
\hline \multicolumn{2}{|c|}{$\begin{array}{l}\text { Homotherium } \\
\text { latidens }\end{array}$} & \multicolumn{2}{|c|}{$\begin{array}{c}\text { Panthera } \\
\text { gombaszoegensis }\end{array}$} & \multicolumn{2}{|c|}{ Equus altidens } & \multicolumn{2}{|c|}{ Axis eurygonos } & \multicolumn{2}{|c|}{$\begin{array}{l}\text { Stephanorhinus cf. } \\
\text { hundsheimensis }\end{array}$} & \multicolumn{2}{|c|}{$\begin{array}{c}\text { Bison (Eobison) } \\
\text { degiulii }\end{array}$} & \multicolumn{2}{|c|}{$\begin{array}{l}\text { Praemegaceros } \\
\text { obscurus }\end{array}$} & \multirow{2}{*}{$\frac{\text { Indeterminate }}{\text { NISP }}$} \\
\hline NISP & MNI & NISP & MNI & NISP & MNI & NISP & MNI & NISP & MNI & NISP & MNI & NISP & MNI & \\
\hline \multirow{3}{*}{1} & & & & & & 1 & 1 & & & & & & & 4 \\
\hline & 1 & & & & & 1 & 1 & & & & & & & \\
\hline & & & & & & $1+1$ & $1+1$ & & & & & & & \\
\hline 1 & 1 & & & 2 & 1 & $\begin{array}{r}12 \\
2\end{array}$ & 1 & 1 & 1 & & & & & 4 \\
\hline \multirow[t]{3}{*}{1} & 1 & & & & & $2+1^{*}$ & $2+1^{*}$ & & & & & & & \\
\hline & & & & $1^{*}$ & $1^{*}$ & 3 & 2 & & & & & & & \\
\hline & & & & & & 8 & 3 & & & & & & & \\
\hline \multirow[t]{2}{*}{2} & 1 & & & 1 & 1 & $3+2$ & $2+1$ & & & & & & & \\
\hline & & & & & & $1+1$ & $1+1$ & & & & & & & \\
\hline \multirow[t]{14}{*}{$1+1$} & $1+1$ & & & & & $1+1^{*+1}$ & $1+1^{*+1}$ & & & & & & & \\
\hline & & & & & & 4 & $3+1^{*}$ & & & & & & & \\
\hline & & & & 1 & 1 & $9+1$ & $2+1$ & & & & & & & \\
\hline & & & & 2 & 1 & 1 & 1 & & & & & & & \\
\hline & & & & $1^{*}$ & $1^{*}$ & & & & & & & & & \\
\hline & & & & & & & & & & & & & & 21 \\
\hline & & & & & & $2+1^{*}$ & $1+1^{*}$ & & & & & & & \\
\hline & & & & & & $1+5^{*}$ & $1^{*}$ & & & & & 1 & 1 & 4 \\
\hline & & 1 & 1 & & & $2+3^{*}+2$ & & & & & & & & \\
\hline & & & & & & & & & & & & & & 1 \\
\hline & & & & 1 & 1 & $8+2$ & $1+1$ & & & & & & & 1 \\
\hline & & & & & & 10 & 2 & & & & & & & \\
\hline & & & & & & 1 & 1 & & & & & & & \\
\hline & & & & & & 1 & & & & & & & & 9 \\
\hline $6+1$ & $1+1$ & 1 & 1 & $7+2^{*}$ & $1+1^{*}$ & $72+11^{*}+\mathbf{1 0}+1$ & $3+1 *+1+1$ & 1 & 1 & & & 1 & 1 & 44 \\
\hline
\end{tabular}

TABLE 5-Extended.

\begin{tabular}{|c|c|c|c|c|c|c|c|c|c|c|c|c|c|c|}
\hline \multicolumn{2}{|c|}{ Homotherium latidens } & \multicolumn{2}{|c|}{$\begin{array}{c}\text { Panthera } \\
\text { gombaszoegensis }\end{array}$} & \multicolumn{2}{|c|}{ Equus altidens } & \multicolumn{2}{|c|}{ Axis eurygonos } & \multicolumn{2}{|c|}{$\begin{array}{l}\text { Stephanorhinus cf. } \\
\text { hundsheimensis }\end{array}$} & \multicolumn{2}{|c|}{$\begin{array}{c}\text { Bison (Eobison) } \\
\text { degiulii }\end{array}$} & \multicolumn{2}{|c|}{$\begin{array}{c}\text { Praemegaceros } \\
\text { obscurus }\end{array}$} & \multirow{2}{*}{$\begin{array}{c}\text { Indeterminate } \\
\text { NISP }\end{array}$} \\
\hline NISP & MNI & NISP & MNI & NISP & MNI & NISP & MNI & NISP & MNI & NISP & MNI & NISP & MNI & \\
\hline & & & & & & 1 & 1 & & & & & & & \\
\hline & & & & & & 1 & 1 & & & & & & & \\
\hline & & & & & & & & & & & & & & 1 \\
\hline & & & & & & 1 & 1 & & & & & & & \\
\hline \multirow[t]{7}{*}{1} & 1 & & & & & & & & & & & & & \\
\hline & & & & & & 1 & 1 & & & & & & & \\
\hline & & & & & & 1 & 1 & & & & & & & \\
\hline & & 1 & 1 & & & 2 & 2 & & & & & & & \\
\hline & & & & & & 1 & 1 & & & & & & & \\
\hline & & & & & & $1^{*}$ & $1^{*}$ & & & & & & & \\
\hline & & & & & & 1 & 1 & & & & & & & \\
\hline \multirow{3}{*}{$\begin{array}{l}1 \\
1\end{array}$} & 1 & & & & & & & & & & & & & \\
\hline & 1 & & & & & & & & & & & & & \\
\hline & & & & & & 1 & 1 & & & & & & & \\
\hline 3 & 1 & 1 & 1 & & & $9+1^{*}+2$ & $2+1 *+1$ & & & & & & & 2 \\
\hline
\end{tabular}




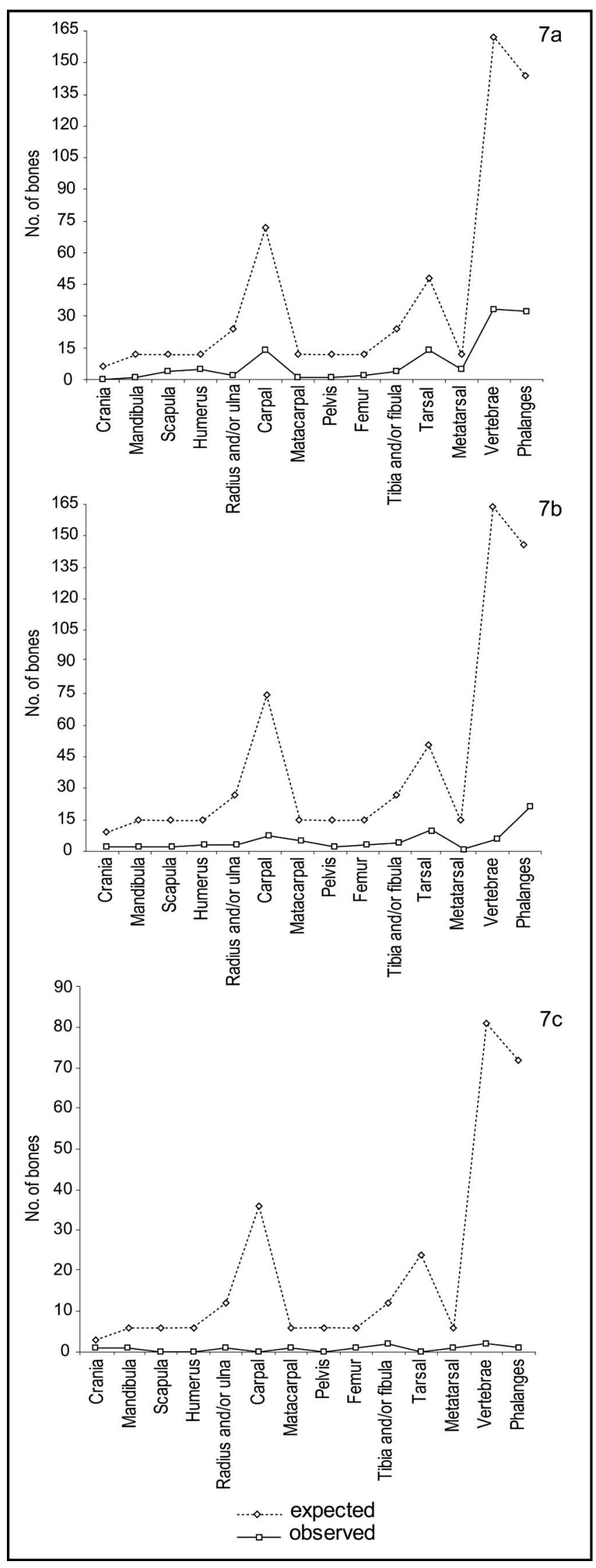

FIGURE 8-Expected versus observed numbers of bones of Axis eurygonos found in the three levels $(7 \mathrm{a}-7 \mathrm{c})$ of SU7. The expected amounts are calculated on the basis of MNI (minimum number of individuals). Taphorecord features have been considered for the determination of MNI
TR III. Different oxide coatings (López-González et al., 2006) or high degrees of abrasion and fracturing are absent. Therefore, we assume an older age for TR III bones as the most probable hypothesis, excluding any reelaboration. A single specimen (PU 124587) referred to TR IV can be recognized as reelaborated as its weathering is inconsistent with its position on the fossiliferous surface (FWS $>$ MWS).

\section{CONCLUSIONS}

The results of the present study on the taphonomy of vertebrate remains from Sedimentary Unit 7 (SU7) at the Pirro 10 site can be summarized by the following: (1) the concept of taphorecord, which has generally been used only for invertebrate taphonomy, is successfully utilized here for vertebrate taphonomy; (2) different taphorecords were identified on the basis of the weathering stages recorded on bone surfaces; (3) using these data, a relative chronological interpretation was assigned to each taphorecord. Taphorecords (TR) I and II comprise bones derived from the same individual or several individuals that died at almost the same time; TR III and IV comprise elements that experienced longer exposure and were either resedimented or reelaborated; (4) the use of taphorecords allows for refinement of the MNI (minimum number of individuals) and NISP (number of identified specimens) parameters that otherwise would have been underestimated; and (5) our analysis of bone orientation suggests that fossiliferous deposits originated by water flows capable of moving bones and sediments. In different SU7 fossiliferous levels, longer phases of carcass accumulation (attritional mortality) alternate with displacement of remains by flow and reelaboration of bones from layers previously deposited. Between accumulation and transport phases in levels $7 \mathrm{a}$ and $7 \mathrm{~b}$, a period of no sedimentation with total or partial exposure of remains is indicated.

Taphonomic analysis of the SU7 assemblages provides the first example of a method that can be used for further studies on other P10 sedimentary units and possibly for similar fossiliferous deposits in cave environments. It is important to define taphorecords that discriminate pre- and postburial features and can thus be used to constrain each fossil assemblage. Even if the entire infilling of the P10 gallery is the result of the action of water flows, the complexity of the karst network does not allow the use of weathering degree as the main characteristic for all vertebrate remains. The connection between the P10 gallery and the open environment probably changed during successive phases of transport and emplacement and for this reason, new parameters such as abrasion degree or oxide coating must be considered together with weathering degree in order to define new taphorecords.

\section{ACKNOWLEDGMENTS}

Fieldwork was supported by University Ministry grants 2006044074_002 (under the direction of G. Pavia, Torino) and by Italcementi Groups, Cassa di Risparmio di Torino Foundation, and Compagnia di San Paolo Foundation. We thank the Apricena Municipality, in particular Major Vito Zuccarino, for logistic and financial support during fieldwork; Giuseppe Andreassi, Annamaria Tunzi, and Ginevra D'Onofrio of the Soprintendenza Archeologica della Puglia for their support in obtaining Ministry permission and during various activities; colleagues from the Universities of Torino, Roma, and Ferrara for their help and suggestions during fieldwork; and M. Coltorti and P. Pieruccini for comments on the sedimentology of the site. A special thanks to the quarry owners, Liliana Gervasio and Alessandra Verni, and to quarry agents, Franco and Gaetano Dell'Erba, for their support and help during fieldwork. Thanks to reviewer Bienvenido Martínez-Navarro and Coeditor Edith L. Taylor for their suggestions that greatly improved the paper. Last, but not least, a particular thanks to all the people from various countries who attended the three excavation campaigns and without whom this work would not have been possible. 
A
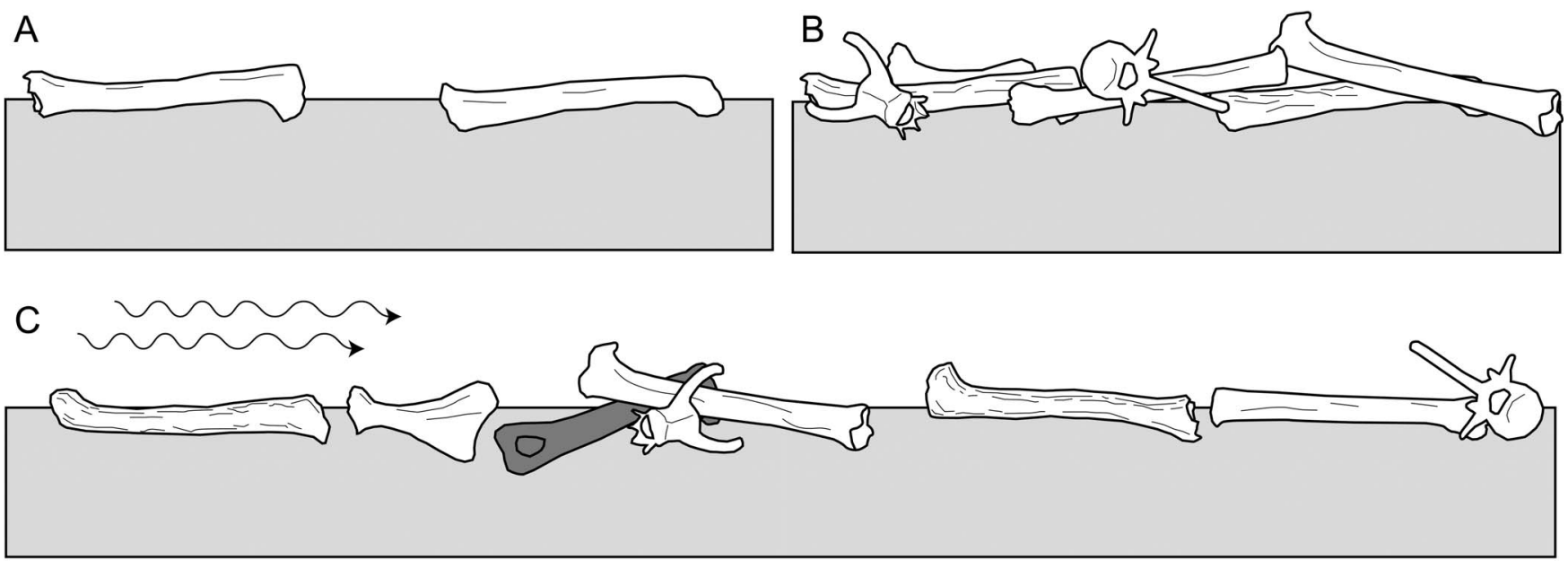

D

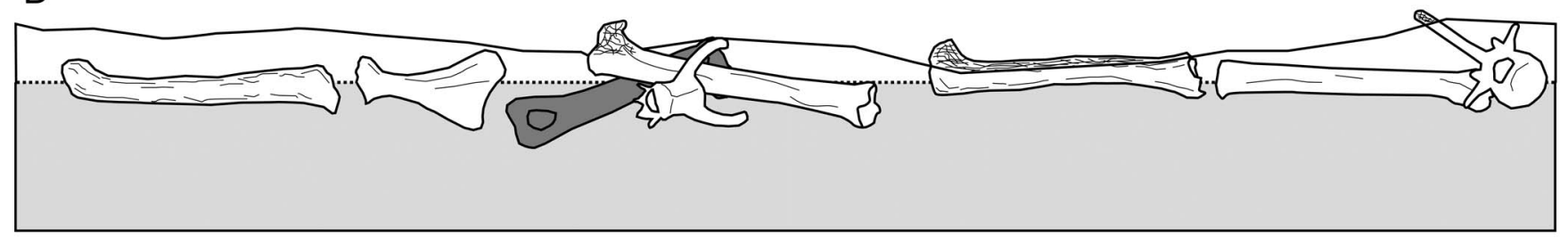

E

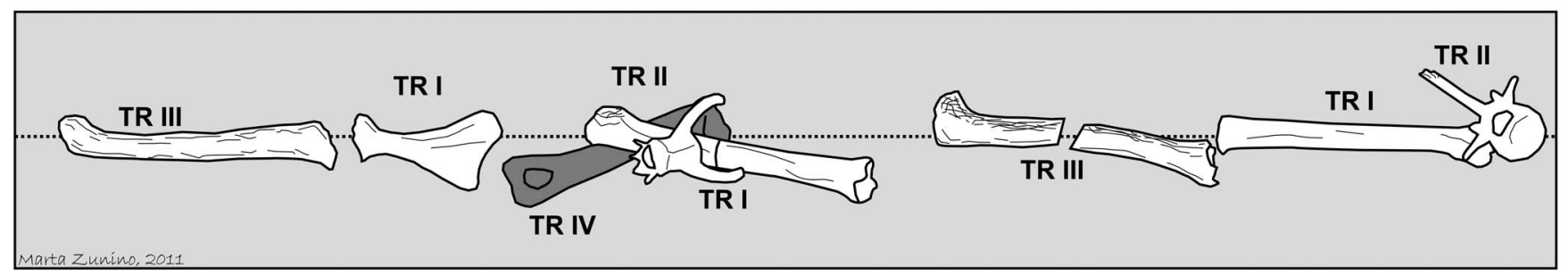

FIGURE 9-Schematic model showing interpretation of successive processes that contributed to the SU7 fossil vertebrate assemblages. Different degrees of weathering are graphically represented by thin lines on bones. The gray bone represents a reelaborated element and the white bones, resedimented elements. A-B) Attritional accumulation and resedimentation of remains (Phase 1). C) Transport by flows (wavy arrows) and subsequent displacement of resedimented or reelaborated bones (Phase 2). D) Partial burial with some exposed portions of bones (Phase 3). E) Complete burial showing different preservation states due to mixing of taphorecords (TR I-TR IV). See text for further explanation.

\section{REFERENCES}

Abbazzi, L., Benvenuti, M., Boschian, G., Dominici, S., Masini, F., Mezzabotta, C., Piccini, L., Rook, L., Valleri, G., and Torre, D., 1996, Revision of the Neogene and Pleistocene of the Gargano region (Apulia, Italy). The marine and continental successions and the mammal faunal assemblages in an area between Apricena and Poggio Imperiale (Foggia): Memorie Società Geologica Italiana, v. 51, p. 383-402.

Arribas, A., and PalmQvist, P., 1998, Taphonomy and palaeoecology of an assemblage of large mammals: Hyaenid activity in the Lower Pleistocene site at Venta Micena (Orce, Guadix-Baza Basin, Granada, Spain): Géobios, v. 31, p. 347.

Arzarello, M., Marcolini, F., Pavia, G., Pavia, M., Petronio, C., Petrucci, M., Rook, L., and Sardella, R., 2007, Evidence of earliest human occurrence in Europe: The site of Pirro Nord (Southern Italy): Naturwissenschaften, v. 94, p. 107-112.

Arzarello, M., Marcolini, F., Pavia, G., Pavia, M., Petronio, C., Petrucci, M., Rook, L., and SARdella, R., 2009, L'industrie lithique du site pléistocène inférieur de Pirro Nord (Apricena, Italie du sud): Une occupation humaine entre 1,3 et 1,7 Ma.: l'Anthropologie, v. 113, p. 47-58.

Arzarello, M., Pavia, G., Peretto, C., Petronio, C., and Sardella, R., 2011, Evidence of an Early Pleistocene hominin presence at Pirro Nord (Apricena, Foggia, South Italy): P13 site: Quaternary International, doi: 10.1016/ j.quaint.2011.01.042.
BAdgLEY, C.E., 1986, Taphonomy of mammalian fossil remains from Siwalik rocks of Pakistan: Paleobiology, v. 12, p. 119-142.

Barone, R., 1995, Anatomia Comparata dei Mammiferi Domestici. Volume Primo Osteologia: Edagricole, Bologna, Italy, 690 p.

Behrensmeyer, A.K., 1975, The taphonomy and paleoecology of Plio-Pleistocene vertebrate assemblages east of Lake Rudolf, Kenya: Bulletin of the Museum of Comparative Zoology, v. 146, p. 474-578.

Behrensmeyer, A.K., 1978, Taphonomic and ecologic information from bone weathering: Paleobiology, v. 4, p. 150-162.

Behrensmeyer, A.K., 1991, Terrestrial vertebrate accumulations, in Allison, P.A., and Briggs, D.E.G., eds., Taphonomy: Releasing the Data Locked in the Fossil Record: Topics in Geobiology, vol. 9, Plenum Press, New York, p. 291-327.

Bertini, A., Ciaranfi, N., Marino, M., and Palombo, M.R., 2010, Proposal for Pliocene and Pleistocene land-sea correlation in the Italian area: Quaternary International, v. 219, p. 95-108.

BraIn, C.K., 1981, The Hunters or the Hunted? An Introduction to African Cave Taphonomy: University of Chicago Press, Chicago and London, 365 p.

Byers, D.A., 2002, Taphonomic analysis, associational integrity and depositional history of the Fetterman mammoth, eastern Wyoming, U.S.A.: Geoarchaeology, v. 17, p. $417-440$.

CoArd, R., 1999, One bone, two bones, wet bones, dry bones: Transport potentials under experimental conditions: Journal of Archaeological Science, v. 26, p. 1369 1375 . 
Conrd, R., and Dennell, R.W., 1995, Taphonomy of some articulated skeletal remains: Transport potential in an artificial environment, Journal of Archaeological Science, v. 22, p. 441-448.

Coombs, M.C., and Coombs, W.P., 1997, Analysis of the geology, fauna and taphonomy of Morava Ranch quarry, early Miocene of northwest Nebraska: PALAIOS, v. 12, p. 165-187.

De Giuli, C., Masini, F., Torre, D., and Boddi, V., 1987, Endemism and biochronological reconstructions: The Gargano case history: Bollettino della Società Paleontologica Italiana, v. 25, p. 267-276.

Díez, J.C., Fernández-Jalvo, J., Rosell, J., and Cáceres, I., 1999, Zooarchaeology and taphonomy of Aurora Stratum (Gran Dolina, Sierra de Atapuerca, Spain): Journal of Human Evolution, v. 37, p. 623-652.

Fernández-JALvo, Y., 1996, Small mammal taphonomy and the middle Pleistocene environments of Dolina, northern Spain: Quaternary International, v. 33, p. 21-34.

Fernández-Jalvo, Y., Denys, C., Andrews, P., Williams, T., Dauphin, Y., and Humphrey, L., 1998, Taphonomy and palaeoecology of Olduvai Bed-I (Pleistocene, Tanzania): Journal of Human Evolution, v. 34, p. 137-172.

Fernández-Jalvo, Y., SÁnchez-Chillón, B., Andrews, P., Fernández-López, S., and Alcalá Martinez, L., 2002, Morphological taphonomic transformations of fossil bones in continental environments, and repercussions on their chemical composition: Archaeometry, v. 44, p. 353-361.

FERNÁNDEZ-LÓPEZ, S.R., 1987, Unidades registráticas, biocronología y geocronología: Revista Española de Paleontología, v. 2, p. 65-85.

FERNÁNDEZ-LÓPEZ, S.R., 1991, Taphonomic concepts for a theoretical biochronology: Revista Española de Paleontología, v. 6, p. 37-49.

FERnÁNDEZ-López, S.R., 2007, Ammonoid taphonomy, palaeoenvironments and sequence stratigraphy at the Bajocian/Bathonian boundary on the Bas Auran area (Subalpine Basin, SE France): Lethaia, v. 40, p. 377-391.

FERNÁNDEZ-LóPEZ, S.R., 2011, Taphonomic analysis and sequence stratigraphy of the Albarracinites beds (lower Bajocian, Iberian Range, Spain). An example of shallow condensed section: Bulletin de la Société Géologique de France, v. 182, p. 405-415.

FioriLlo, A.R., 1991, Taphonomy and depositional setting of Careless Creek Quarry (Judith River Formation), Wheatland County, Montana, U.S.A.: Palaeogeography, Palaeoclimatology, Palaeoecology, v. 81, p. 281-311.

Freudenthal, M., 1971, Neogene vertebrates from the Gargano Peninsula, Italy: Scripta Geologica, v. 3, p. 1-10.

Gliozzi, E., Abbazzi, L., Azzaroli, A., Caloi, L., Capasso Barbato, L., Di Stefano, G., Esu, D., Ficcarelli, G., Girotti, O., Kotsakis, T., Masini, F., Mazza, P., Mezzabotta, C., Palombo, M.R., Petronio, C., Rook, L., Sala, B., Sardella, R., Zanalda, E., and Torre, D., 1997, Biochronology of selected mammals, molluscs and ostracods from the Middle Pliocene to the Late Pleistocene in Italy. The state of the art: Rivista Italiana Paleontologia e Stratigrafia, v. 90, p. 369-388.

Gómez, J.J., and Fernández-López, S., 1994, Condensation processes in shallow platforms: Sedimentary Geology, v. 92, p. 147-159.

Grassi, D., Romanazzi, L., Salvemini, A., and Spilotro, G., 1982, Grado di evoluzione e ciclicità del fenomeno carsico in Puglia in rapporto all'evoluzione tettonica: Geologia Applicata e Idrogeologia, v. 17, p. 55-73.

Grayson, D.K., and Frey, C.J., 2004, Measuring skeletal part representation in archaeological faunas: Journal of Taphonomy, v. 2, p. 27-42.

Hill, A., and Behrensmeyer, A.K., 1984, Disarticulation patterns of some modern East African mammals: Paleobiology, v. 10, p. 366-376.

JACKSON, J.A., ed., 1997, Glossary of Geology: American Geological Institute, Alexandria, Virginia, 769 p.

Karcz, I., 1968, Fluviatile obstacle marks from the wadis of the Negev (Southern Israel): Journal of Sedimentary Petrology, v. 38, p. 1000-1012.

Kaufmann, C.A., Gutiérrez, M.A., Álvarez, M.C., González, M.E., and Massigoge, A., 2010, Fluvial dispersal potential of guanaco bones (Lama guanicoe) under controlled experimental conditions: The influence of age classes to hydrodynamic behavior: Journal of Archaeological Science, v. 38, p. 334-344.

Kos, A.M., 2003, Characterization of post-depositional taphonomic processes in the accumulation of mammals in a pitfall cave deposit from southeastern Australia: Journal of Archaeological Science, v. 30, p. 781-796.

López-González, F., Grandal-d’Anglade, A., and Vidal-Romaní, J.R., 2006, Deciphering bone depositional sequences in caves through the study of manganese coatings: Journal of Archaeological Science, v. 33, p. 707-717.
Lyman, R.E., 1994, Vertebrate Taphonomy: Cambridge University Press, Cambridge, UK, $524 \mathrm{p}$.

Lyman, R.E., and Fox, G.L., 1989, A critical evaluation of bone weathering as an indication of bone assemblage formation: Journal of Archaeological Science, v. 16, p. 293-317.

Martire, L., and Torta, S., 2000, Pseudoborings in ammonite molds: The combined result of predation and taphonomic-reworking (Bajocian, Normandy, N. France): PALAIOS, v. 15, p. 356-362.

Masini, F., and SALA, B., 2007, Large- and small-mammal distribution patterns and chronostratigraphic boundaries from the Late Pliocene to the Middle Pleistocene of the Italian peninsula: Quaternary International, v. 160, p. 43-56.

Mazza, P.A., Bertini, A., and Magi, M., 2004, The Late Pliocene site of Poggio Rosso (Central Italy): Taphonomy and paleoenvironment: PALAIOS, v. 19, p. 227-248.

Pavia, G., and Pavia, M., 2004, Criteri di catalogazione delle collezioni paleontologiche del Museo di Geologia e Paleontologia dell'Università di Torino: Il caso dei molluschi del Messiniano di Borelli (Torino): Bollettino del Museo Regionale di Scienze Naturali di Torino, v. 21, p. 203-226.

Pavia, G., Arzarello, M., Marcolini, F., Pavia, M., Petronio, C., Petrucci, M., Rook, L., and Sardella, R., 2008, Ricerche antropologiche, paleontologiche e stratigrafiche sul sito pleistocenico di Pirro Nord, Foggia: Evidenze della più antica occupazione umana in Europa: Geoingegneria Ambientale e Mineraria, p. 149153.

Pavia, G., Bertok, C., Ciampo, G., Di Donato, V., Martire, L., Masini, F., Pavia, M., Santangelo, N., Taddei Ruggiero, E., and Zunino, M., 2010, Tectonosedimentary evolution of the Pliocene to Lower Pleistocene succession of the Apricena-Lesina-Poggio Imperiale quarrying district (western Gargano, southern Italy): Bollettino della Società Geologica Italiana, v. 129, p. 132-155.

Pavia, M., Zunino, M., Coltorti, M., Angelone, C., Arzarello, M., Bagnus, C., Bellucci, L., Colombero, S., Marcolini, F., Peretto, C., Petronio, C., Petrucci, M., Pieruccini, P., Sardella, R., Tema, E., Villier, B., and Pavia, G., 2011, Stratigraphical and palaeontological data from the Early Pleistocene Pirro 10 site of Pirro Nord (Puglia, south-eastern Italy): Quaternary International, doi: 10.1016/ j.quaint.2010.12.019.

Pfeiffer, T., 1999, Die Stellung von Dama (Cervidae, Mammalia) im System plesiocarpaler hirsche des Pleistozäns: Courier Forschungsinstitut Senckenberg, v. 211, p. 1-218.

Potтs, R., 1986, Temporal span of bone accumulations at Olduvai Gorge and implications for early hominid foraging behavior: Paleobiology, v. 12, p. 25-31.

Reolid, M., 2008, Taphonomic features of Lenticulina as a tool for paleoenvironmental interpretation of midshelf deposits of the Upper Jurassic (Prebetic Zone, Southern Spain): PALAIOS, v. 23, p. 482-494.

Rook, L., and Martínez-Navarro, B., 2010, The long story of a Plio-Pleistocene European large mammal biochronologic unit: Quaternary International, v. 219, p. $134-144$.

Rook, L., and Sardella, R., 2005, Hystrix refossa Gervais, 1852 from Pirro Nord (Early Pleistocene, Southern Italy): Rivista Italiana di Paleontologia e Stratigrafia, v. 111, p. 489-496.

Rustioni, M., and Mazza, P., 2001, Taphonomic analysis of Tapirus arvernensis remains from the lower Valdarno (Tuscany, Central Italy): Géobios, v. 34, p. 469474.

Rygel, M.C., Gibling, M.R., and Calder, J.H., 2004, Vegetation-induced sedimentary structures from fossil forests in the Pennsylvanian Joggins Formation, Nova Scotia: Sedimentology, v. 51, p. 531-552.

Simms, M.J., 1994, Emplacement and preservation of vertebrates in caves and fissures: Zoological Journal of the Linnean Society, v. 112, p. 261-283.

Tema, E., Lanza, R., and Pavia, G., 2009, Paleomagnetic study of the Pirro Nord sedimentary fill, in Società Paleontologica Italiana, ed., Giornate di Paleontologia 2009, Abstract Volume: Società Paleontologica Italiana, p. 56.

Villa, P., and Mahieu, E., 1991, Breakage patterns of human long bones: Journal of Human Evolution, v. 21, p. 27-48.

Voorhies, M.R., 1969, Taphonomy and population dynamics of an Early Pliocene vertebrate fauna, Knox County, Nebraska: University of Wyoming Contributions to Geology, Special Paper, v. 1, 69 p.

\section{ACCEPTED SEPTEMBER 21, 2011}


